DOE/METC--91/0272

DE91 002002

\title{
Instrumentation and Diagnostics
}

\author{
Technology Status Report
}

\author{
C. V. Nakaishi \\ R. C. Bedick
}

\begin{abstract}
U.S. Department of Energy
Office of Fossil Energy

Morgantown Energy Technology Center

P.O. Box 880

Morgantown, West Virginia 26507-0880
\end{abstract}

December 1990

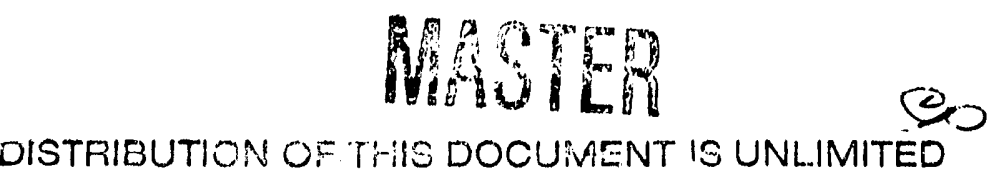


Contributions from all the investigators involved in the AR\&TD Instrumentation and Diagnostics Projects have made this report possible and are very much appreciated. In addition, the support from both the METC AR\&TD Coordinator, John W. Byam, Jr., and the DOE/FE Program Manager, Charles W. Garrett, is recognized. Technical Writing Services of EG\&G, Frank Kerns of the Associated Oak Ridge University, and Steven Bossart, Robert Reuther, Gregg Huston, Jan Wachter, and Larry Headley of DOE/METC helped prepare this report. 


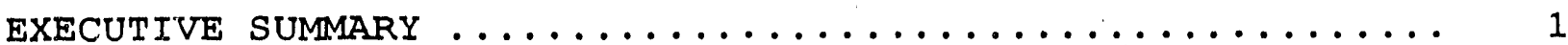

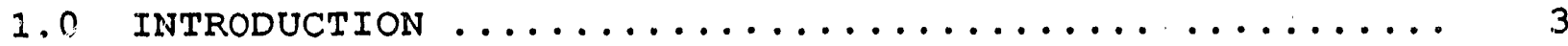

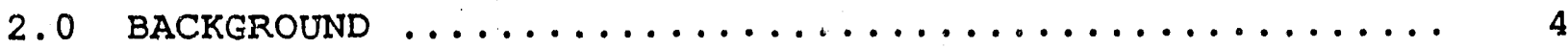

3.0 ACTIVITIES ......................... 5

3.1 Chemical Analysis .................... 6

3.2 Earticle Characterization ................ 10

3.3 Thermophysical Properties ................ 14

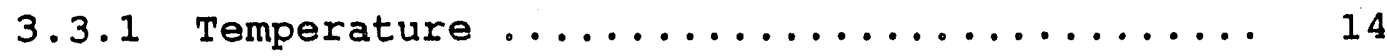

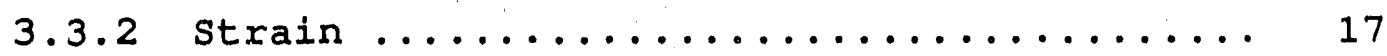

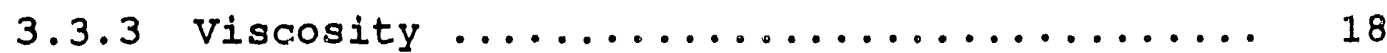

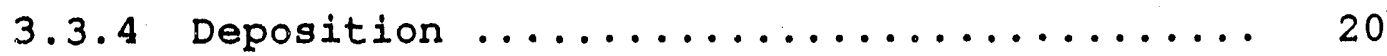

3.4 Process Control systems .................. 21

3.5 Multiphase Elow Characterization ........... 22

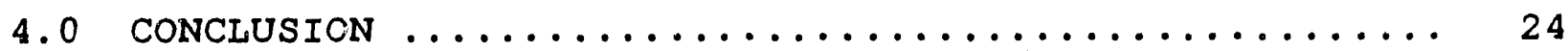

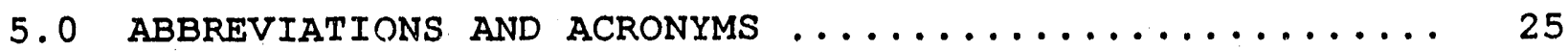

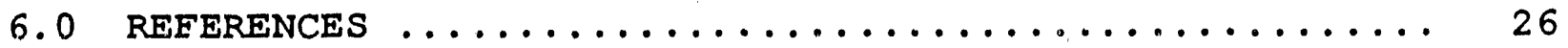

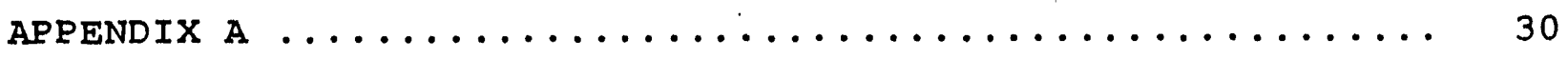




\section{LIST OF FIGURES}

Eigure

Page

1 Simplified Advanced Coal-Based System,

Focus for Instrumentation and Diagnostics ......

2 Schematic of the Inductively Coupled Plasma

spectroscopy Torch ....................

The METC Laser Indured Breakdown Spectroscopy

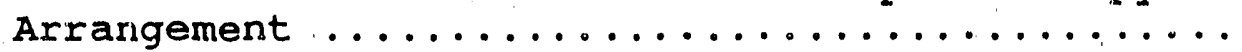

4 The Laboratory Arrangement of the Photofragment Fluorescence Spectroscopy for Alkali

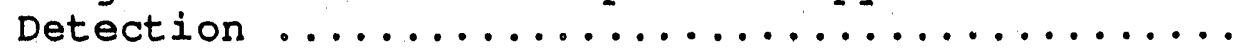

5 Laboratory Test Setup for Laser Spark

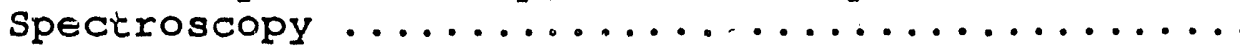

Configuration of the Dual-Beam Laser Doppler Velocimeter

A Simplified Schematic of the Fluorescence

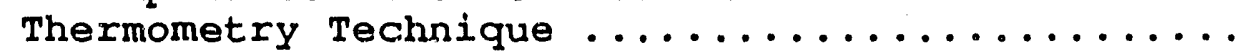

Experimental Setup for Testing Multiple

Fiber Optic Air-Gap Strain Sensors ...........

Aluminum Acoustical Wedge Used to Determine

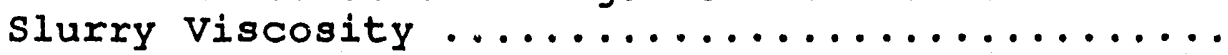




\section{EXECUTIVE SUMMARY}

This Technclogy status Report describes research and accomplishments for the Instrumentation and Diagnostics (I\&D) Projects within the Advanced Research and Technology Development (AR\&TD) Program of the United States Department of Energy (DOE) Office of Fossil Energy (FE).

Process understanding and control can be improved through the development of adranced instrumentation and diagnostics. The thrust of the I\&D Projects is to further develop existing measurement and control techniques for application to advanced coalbased technologies. Instrumentation and diagnostics assists in the commercialization of advanced coal technologies by furnishing information that leads to increased system efficiencies, reduced capital and operating costs, decreased solid waste generation, and reduced pollutant emissions.

The projects are grouped according to chemical analysis, particle characterization, thermophysical properties, process control systems, and inultiphase flow characterization. The following are project highlights.

- Chemical Analysis: An inductively coupled plasma (ICP) instrument has been developed to analyze trace elements in gasification and combustion process streams. Laser-induced breakdown spectroscopy (LIBS) or laser spark spectroscopy (LSS) can be used for in situ analysis of gases, particles, and deposits, although in situ calibration is still needed. In addition, a laser-based optical diagnostic technique based on photodissociation has been developed to monitor trace levels of alkali compounds in situ. The technique promises to be compatible with the harsh conditions of coal combustion.

- Particle Characterization: An in situ two-color Mie scattering technique with LSS can simultaneously measure the size, velocity, and elemental composition of coal particles duxing combustion. Optimal configurations have been identified for measuring particle sizes from laser Doppler velocimeter signals. Milimeter wave spectroscopy can be used to measure the temperature of particles and nay be able to measure the composition of major gas species and the gasphase temperature.

- Thermophysical Properties: A high-temperature, fluorescence thermometry technique has accurately measured gas temperatures during field testing in combustion and gasification environments. A sodium line emission pyrometer has measured temperatures in a coal combustor. "Smart" optical fibers 
were installed on a ceramic cross-flow filter and successfully detected strains caused by changes in process conditions.

- Process Control Systems: Expert systems have been developed to improve the control of advanced coal-based processes. Specifically, a control scheme was developed, which tunes the proportional and integral gains to position a particle in an electrodynamic balance, and a bed level monitor was designed for a fixed-bed gasifier system.

- Multiphase Flow Characterizations: Capacitance flowmeters were developed to determine the mass flowrate, solid volume fraction, and particle velocities of coal slurries. 


\subsection{INTRODUCTION}

This Technology status Report summarizes AR\&TD I\&D Projects. These I\&D techniques measure and control process conditions in advanced coal-based conversion and utilization technologies. Some promising advanced coal-based technologies include pressurized fluidized-bed (PFB) combustion combined-cycle systems, integrated gasification combined-cycle (IGCC) systems, direct coal-fired gas turbines, coal-fueled diesels, and fuel cells. The development of new and efficient advanced coal-based systems has created an urgent need for understanding these processes, monitoring key parameters, and controlling the critical functions. Determining the effects of process parameters can show the potential advantages of the process, as well as its limitations. Information derived from instrumentation measurements is useful in scaling the process to larger sizes and in developing economics.

Frequently, off-the-shelf instrumentation and diagnostics do not meet the special requirements imposed by FE processes. The main thrust of the I\&D Projects is to determine measurement requirements and modify the latest instrumentation to meet those requirements, although new instrumentation techniques have been initiated. The goal of I\&D Projects is to demonstrate feasibility. It is anticipated that the private sector will commercialize viable instrumentation and diagnostics techniques that were demonstrated in the AR\&TD program.

Developing instrumentation requires knowledge of the processes and an understanding of instrumentation behavior in different environments. Advanced FE processes can be a difficult application for instrumentation. The environments of advanced FE processes are typically high-temperature, high-pressure (HTHP), corrosive, erosive, and dynamic. It is desirable to have crosscutting techniques that have applications for many processes. Data are needed to improve system efficiencies, reduce pollutant formation, and curtail waste disposal in the advanced $\mathrm{FE}$ processes. 


\subsection{BACKGROUND}

Severai reports describe instrumentation and diagnostics for energy applications (Nelson et al. 1987; Haran 1986; Hardesty 1984; Liptak and Leiter 1980; O'Fallon et al. 1976). These reports identify instrumentation needs, assess available instrumentation, and describe instrumentation techniques. The status of many AR\&TD instrumentation and diagnostic projects is included in Contractors Meeting Proceedings (Gailing and Goldberg 1989; Hickerson 1988; and Holcombe 1987). In addition, DOE's Morgantown Energy. Technology Center (METC) has created an information system to track FE instrumentaticn research efforts. This information system stores and organizes abstracts from published documents on EE instrumentation research. Appendix A provides a list of abstracts arranged by author that were in the information system database as of July, 1990.

Many advanced coal-based processes require HTHP operating conditions to achieve lihe efficiencies necessary to be cost effective. Intrusive sensors must be mechanically strong and resistant to both chemical attack and particle erosion in these environments. Coal contains species that can react with materials of construction to cause corrosive fillures. Chemical attack or corrosion is mainly a function of temperature and composition. Erosion is primarily a function of particle size and stream velocity. The mineral matter in coal can produce particles of sufficient size to be very erosive.

Figure 1 is a schematic of a simplified advanced coal-based system. The shaded area shows where the most "challenging" operating conditions exist and is the area of emphasis for most of the AR\&TV I\&D Projects research. This area begins with feecing coal into the conversion units (gasifier or PFB combustor) and ends after the gas turbine. Typical operating conditions for this system are temperatures greater than $800 \mathrm{~K}$ and pressures greater than 10 bar. This system includes both oxidizing and reducing gas environments.

Hot gas cleanup approaches are especially targeted for diagnostics development. Hot gas cleanup devices remove coal-dezived contaminants, including particles, sulfur, and trace metals. system efficiencies remain high because these contaminants are removed from the hot process streams without the significant loss of thermal energy. In coal gasification systems, it is advantageous to remove contaminants prior to combustion. The lower gas volume upstream of the combustor results in smaller vessels, and thus reduces the capital costs. 


\subsection{ACTIVITIES}

I\&D Project descriptions have been grouped by activities. These activities are chemical analysis, particle characterization, thermophysical properties, process control systems, and multiphase flow characterization. The investigations include development of sensors to measure key parameters, improvements to methods for transferring signals, refinements to diagnostics to quantify and understand the processes, and development of control systems to regulate the processes. Many of the instrumentation and diagnostics methods can be applied to several advanced coal processes. The process conditions dictate the specific requirements for temporal resolution, spatial resolution, sensitivity, selectivity, and durability. Non-intrusive and real-time measurements are desirable so that processes are not changed by the act of measuring and so that diagnostics can be performed as the processes take place.

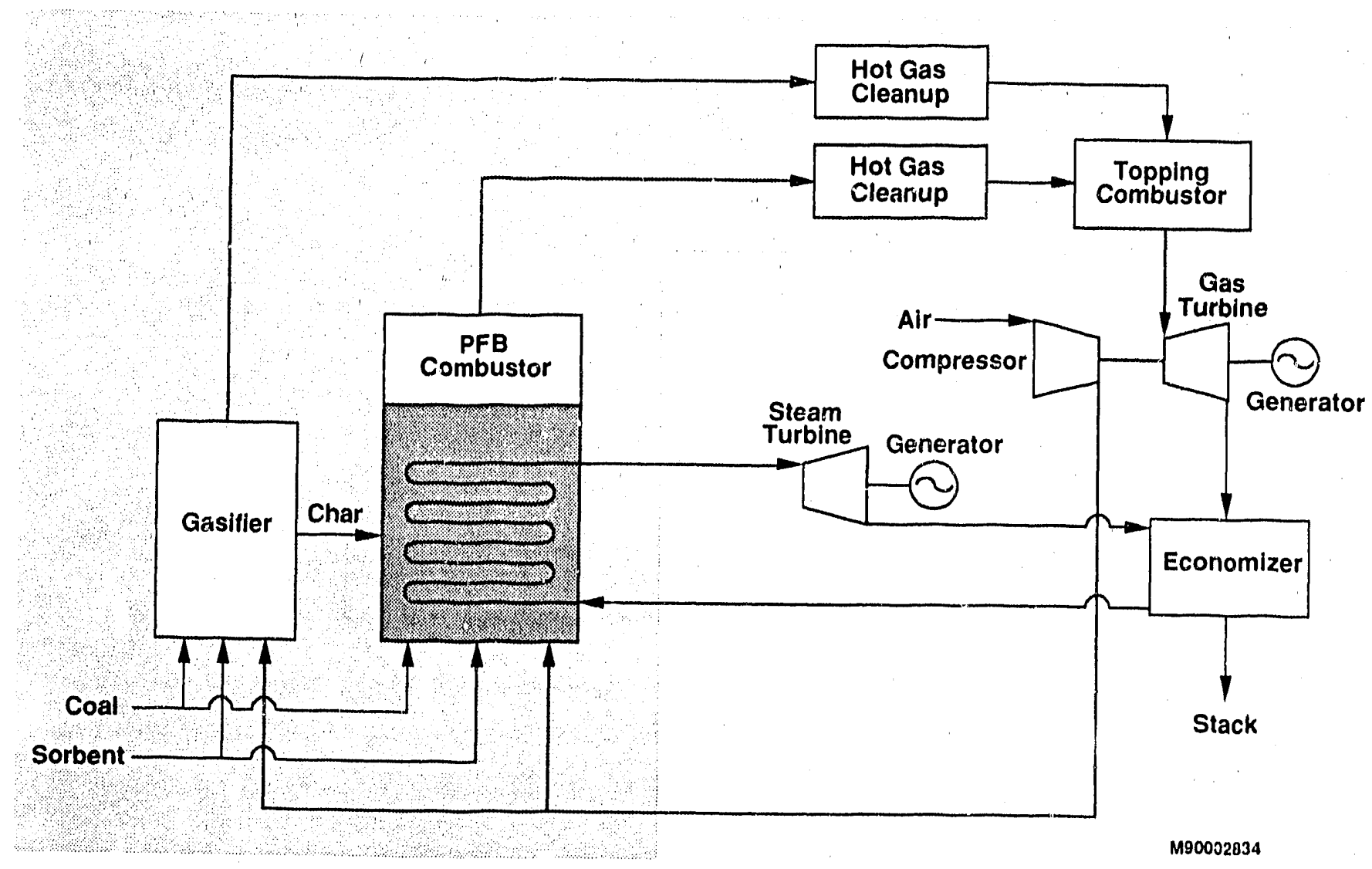

\section{Figure 1. Simplified Advanced Coal-Based System, Focus for Instrumentation and Diagnostics}




\subsection{Chemical Analysis}

Coal is a chemically and physically heterogeneous material that consists principally of carbon, hydrogen, and oxygen with lesser amounts of sulfur and nitrogen. Other constituents include the ash-forming inorganic compounds that are distributed as discrete particles of mineral matter throughout the coal substance or as atomically dispersed elements associated with the organic fraction (Elliott 1981). Advanced coal-based processes convert the coal into combustible gases, char, or -iquid products. During this conversion, contaminants can be released from the coal.

Historically, extractive sampling techniques have been used to determine the composition of the process gas streams. Gas chromatography and mass spectroscopy are on-line methods that are used to routinely analyze major gas constituents. The trace species composition of a process gas stream can charge rapidly because of normal variations in coal composition. Thus, realtime measurements of trace contaminants under HTHP conditions remains a challenge. Real-time measurements are needed for controlling contaminant cleanup systems. Off-line analyses in the laboratory are not sufficiently responsive for control of the contaminant cleanup systems. Without a real-time measurement and control system, the downstream equipment may be damaged or the process may pollute the environment. For example, determining the amount of sulfur and alkali will assist in understanding the mechanisms of hot corrosion of turbine blades. In addition, measurements can track the gradual performance detexioration of mixed-metal oxide desulfurization sorbents. Contaminants can be divided into the following groups (Nelson et al. 1987):

Sulfur Compounds: Nitrogen Compounds: Halogen Compounds: Trace Elements: Hydrocarbons :
$\mathrm{H}_{2} \mathrm{~S}, \mathrm{COS}, \mathrm{CS}_{2}, \mathrm{RSH}$, Thiophene, $\mathrm{SO}_{2}, \mathrm{SO}_{3}$ $\mathrm{NH}_{3}, \mathrm{HCN}, \mathrm{HCNS}, \mathrm{NO}_{x}$ $\mathrm{Cl}_{2}$, $\mathrm{HCl}$, $\mathrm{HF}, \mathrm{HBr}, \mathrm{x}$ alkali halides $\mathrm{As}^{2} \mathrm{Cd}, \mathrm{Ge}, \mathrm{Hg}, \mathrm{Pb}, \mathrm{Se}, \mathrm{Sn}, \mathrm{Te}, \mathrm{V}, \mathrm{Zn}$ $\mathrm{CH}_{4}, \mathrm{C}_{2} \mathrm{H}_{6}$, benzene, toluene, phenols, oils, tars

The following are the I\&D Projects for developing chemical analysis techniques. 
On-Line Extractive Methods for Elemental Analysis (Morgantown Energy Technology Center) -- The purpose is to develop ICP spectroscopy to analyze trace elements.

An ICP spectrometer is being dereloped and modified to analyze a slip stream extracted from process gas for elemental (percentage, minor, and trace) constituents. The ICP can analyze both gas phase and particles in a process stream. The ICP operates using an inert gas torch. The torch receives radio frequency energy through copper coils surrounding a quartz tube. A spark begins a cascade reaction of electrons, and then the reaction becomes self-sustaining. The plasma can attain temperatures of 6,000 to $10,000 \mathrm{~K}$. The magnetic fields create a doughnut-shaped plasma, which allows the sample to be introduced through the center of the plasma. The sample gas decomposes, the atoms enit light, and the monochromator analyzes the elemental emissions. A schematic of the ICP torch is shown in Figure 2 .

In order to eliminate the typical quenching effects of process gas on the plasma, a high-power (in excess of 4,000 watts) helium-assisted argon plasma has been developed. To. handle high-temperature, particle-laden streams, the plasma torch has been specially designed to accommodate flow rates of 5 liters/minute. The high flow rates ersure that particulate matter in the sampling stream remains entrained. A prototype ICR system constructed for field testing transfers emissions from the plasma via six mini-monochromators. Ea,h monochromator is dedicated to the analysis of a single element. The elements chosen for initial monitoring include $\mathrm{Fe}, \mathrm{Ca}, \mathrm{Mg}, \mathrm{Pb}, \mathrm{Cr}, \mathrm{Cd}, \mathrm{Zn}$, $\mathrm{As}, \mathrm{Se}, \mathrm{Na}$, and $\mathrm{K}$. The detection limits for $\mathrm{Ca}$ and $\mathrm{Mg}$ are in the low parts-per-trillion (ppt) range. The limits for the other elements are in the low parts-per-billion (ppb) range. The ICP has performed successfuliy on a bench-scale pressurized combustor and on a fixed-bed casifier process stream. ICP field tests are planned at the Texaco subpilot-scale gasifier and the Foster Wheeler second-generation PFB combustion system (Romanosky et al. 1989; Geiling and Goldberg 1989; Holcombe 1987).

In Situ Methods for Flemental Analysis of Hot Gas streams by Laser-Induced Breakdown Spectroscopy (Morgantown Energy Technology Center) - The goal is to develop a spatially resolved in situ technique for the elemental analysis of fossil fuel process streams.

IIBS uses a very intense, short pulse of laser light to form a spark in the process stream through an optical window. Spark temperatures of up to $30,000 \mathrm{k}$ fragment all molecules into their constituent atoms. These atoms can be in both excited or ionized forms, which generate light emission at element specific wavelengths. The light emitted from the spark is analyzed to 


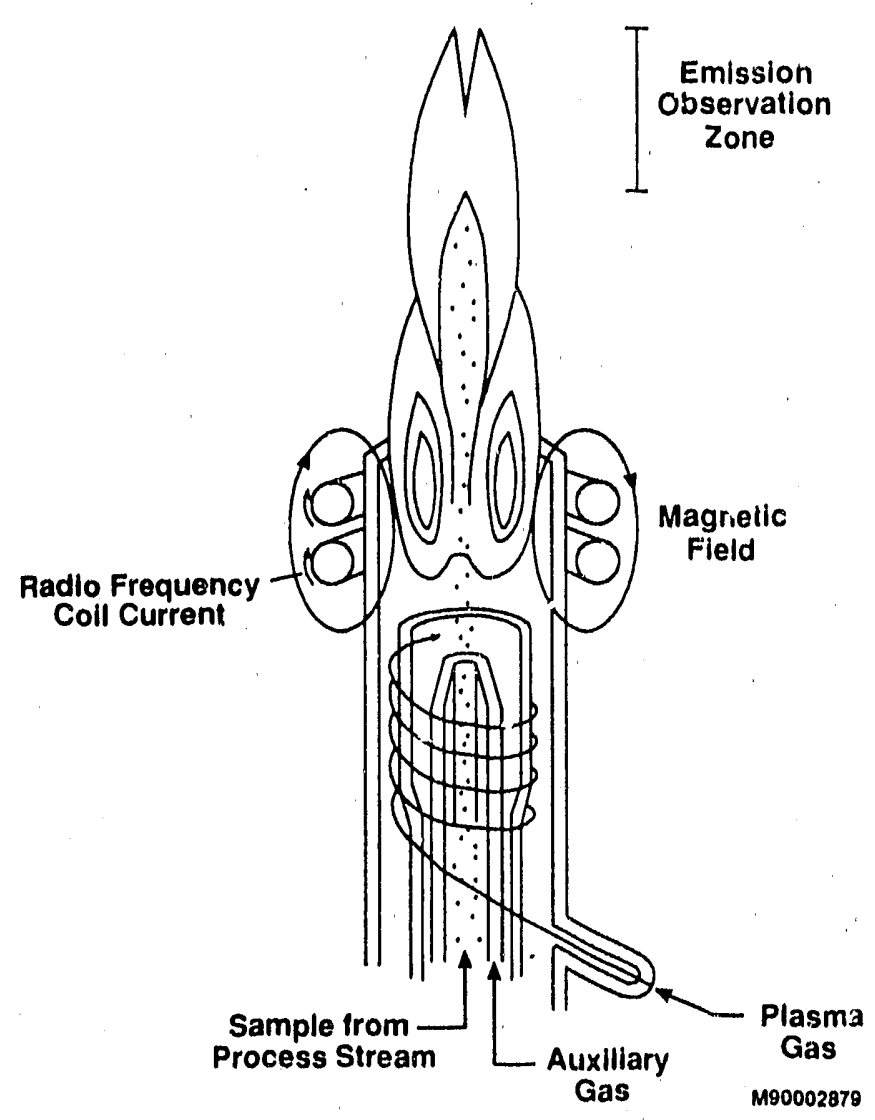

Figure 2. Schematic of the Inductively Coupled Plasma Spectroscopy Torch

determine the elemental composition. LIBS delineates the atomic constituents of either gases or solids. As shown in Figure 3, the METC IIBS includes a Neodymium-doped yttrium aluminum garnet (Nd:YAG) laser and two parallel monochromators for one for analysis and the other for calibration. This LIBS system is unique since it uses only a single optical port for both the laser input and emissions output. Most elemen:s can be detected with a sensitivity in the parts-per-million range. The technique requires multiple light emission measurements to attain this sensitivity. An in situ calibration method is still under development. Recent laboratory work has shown that LIBS can be used for in situ analysis of deposits on the interior surfaces of turbine blades or barrier filters. However, improvement of sensitivity and reduction of noise will be neccssary for the application of this technique to be viable (Chisholm 1989). 


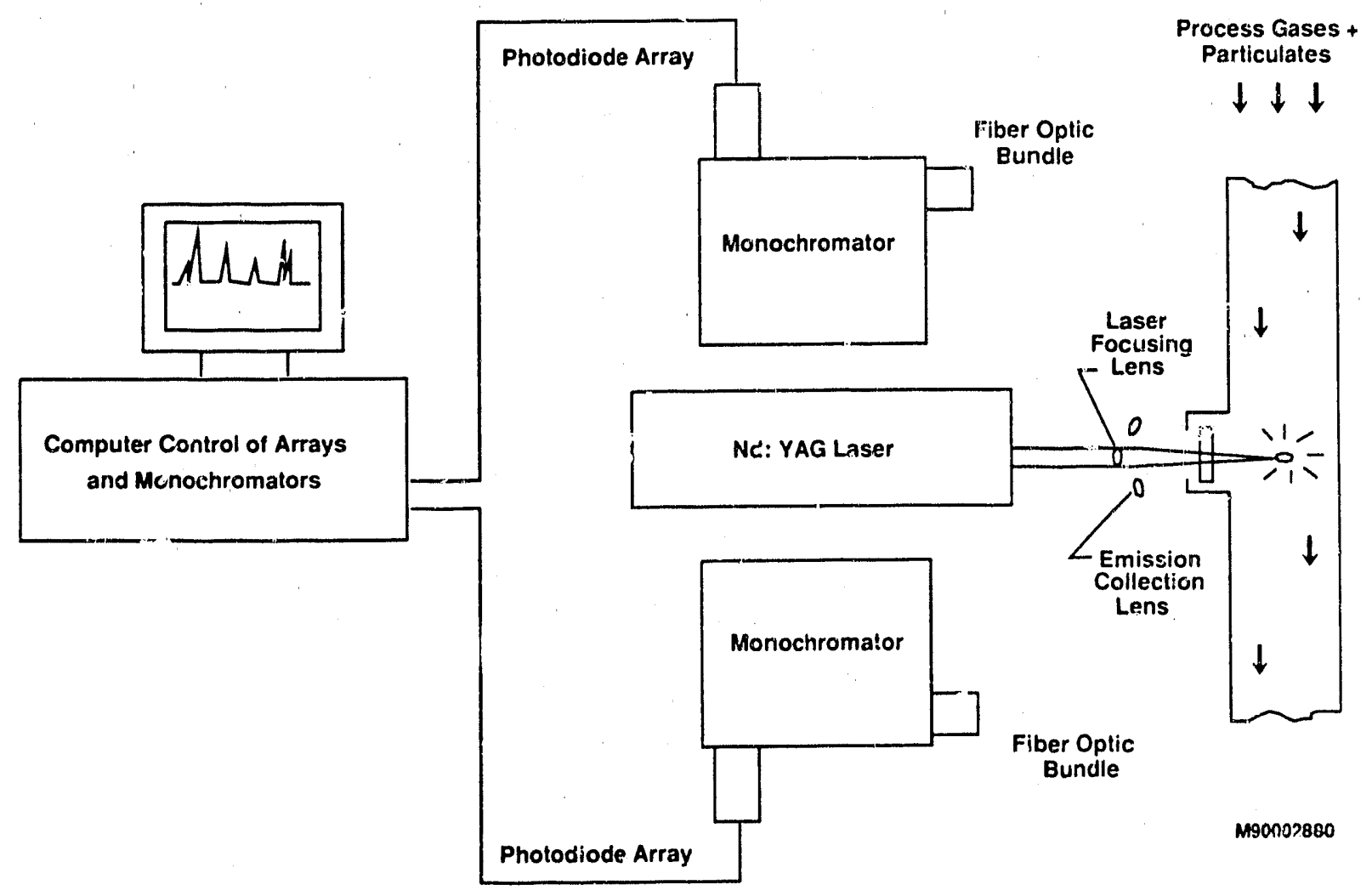

Figure 3. The TSTC Laser Induced Breakdown
Spectrosccpy Arrangement

Optical Detection ef Corrosive Compounds (Los Alamos National Laboratoryl -- The purpose is to develop a laser-based optical diagnostic technique for in situ monitoring of trace levels of alkali compounds in coal-gas combustion streams.

Ultraviolet photodissociation is a spectroscopic property that can be used to detect alkali compounds. This technique uses an ultraviolet laser to excite a compound to a state that dissociates along a repulsive potential to yield an excited alkali atom. This atom then emits light at its characteristic wavelength. The intensity of this emission is proportional to the original concentration of the parent compound. The major advantage of this detection scheme is that it can determine compounds, while most other techniques can only determine elemental composition.

Compounds with different alkali (e.g., $\mathrm{Na}^{+}$and $\mathrm{K}^{+}$) can be readily distinguished by the emission wavelengths of the excited atoms. Discrimination between compounds of the same alkali but 
with different anions (e.g., $\mathrm{Cl}^{-}$and $\left.\mathrm{OH}^{-}\right)$is more difficult. However, it can be achieved by examining the dependence of the alkali emission on the excitation wavelength. Figure 4 shows the laboratory equipment arrangement for alkali detection. The atomic emission intensities correlate with the densities of the alkali compounds for at least five orders of magnitude. As little as $0.03 \mathrm{ppb} \mathrm{NaCl}, 0.08 \mathrm{ppb} \mathrm{NaOH}, 0.4 \mathrm{ppb} \mathrm{KC} . \mathrm{h}$, and $5 \mathrm{ppb}$ KOH can be measured with a single laser pulse, making this a very sensitive diagnostic technique. Results show that this photofragment fluorescence diagnostic technique will be well suited to combustion conditions (Oldenborg 1989).

Investigation of Semiconductor Gas Sensing Devices for Coal Gasification Process Streams (Westinghouse) - - A proof-offeasibility study addressed whether metal oxide semiconductor (MOS) detectors could serve as sensing devices in highly reducing coal gasifier streams.

Semiconductor gas sensors operate by measuring the change in resistance of a material in response to a surrounding gas. The gas reacts with the surface of the semiconductor, or with material previously absorbed on the semiconductor. Then, the charge carriers are either injected, withdrawn, or released. This changes the semiconductor's conductivity. Reactions between the MOS and its surroundings include oxidation or reduction, ion exchange, and absorption. Prior measurements using this technology were made on various gases, including several hydrocarbons and their derivatives, halogenated hydrocarbons, alcohols, ethers, ketones, esters, nitrogen compounds, and inorganics.

This effort addresses whether or not MOS detectors can be reliable sensors in the reducing gas conditions of coal gasification processes. The technique depends on the reaction of the gases with absorbed ionic oxygen species, which releases electrons to the conduction band of the MOS material. Several MOS materials have been shown to be worthy of experimental evaluation. However, the MOS reducing gas sensor can not operate reversibly in a reducing gas environment without some oxygen. Laboratory experiments showed that plasma spraying and sol-gel synthesis would increase the oxygen responsiveness to reducing gas exposure (Mattox 1985; Hubbard and Gordon 1987).

\subsection{Particle Characterization}

Characterization of particles includes determination of size and distribution, shape, velocity, concentration, and trajectory. This characterization is essential to monitoring and understanding processes occurring in coal-fired turbine combustors, coal-fueled diesels, and hot gas particle control devices. Particles larger than 10 micrometers $(\mu \mathrm{m})$ can erode turbine 


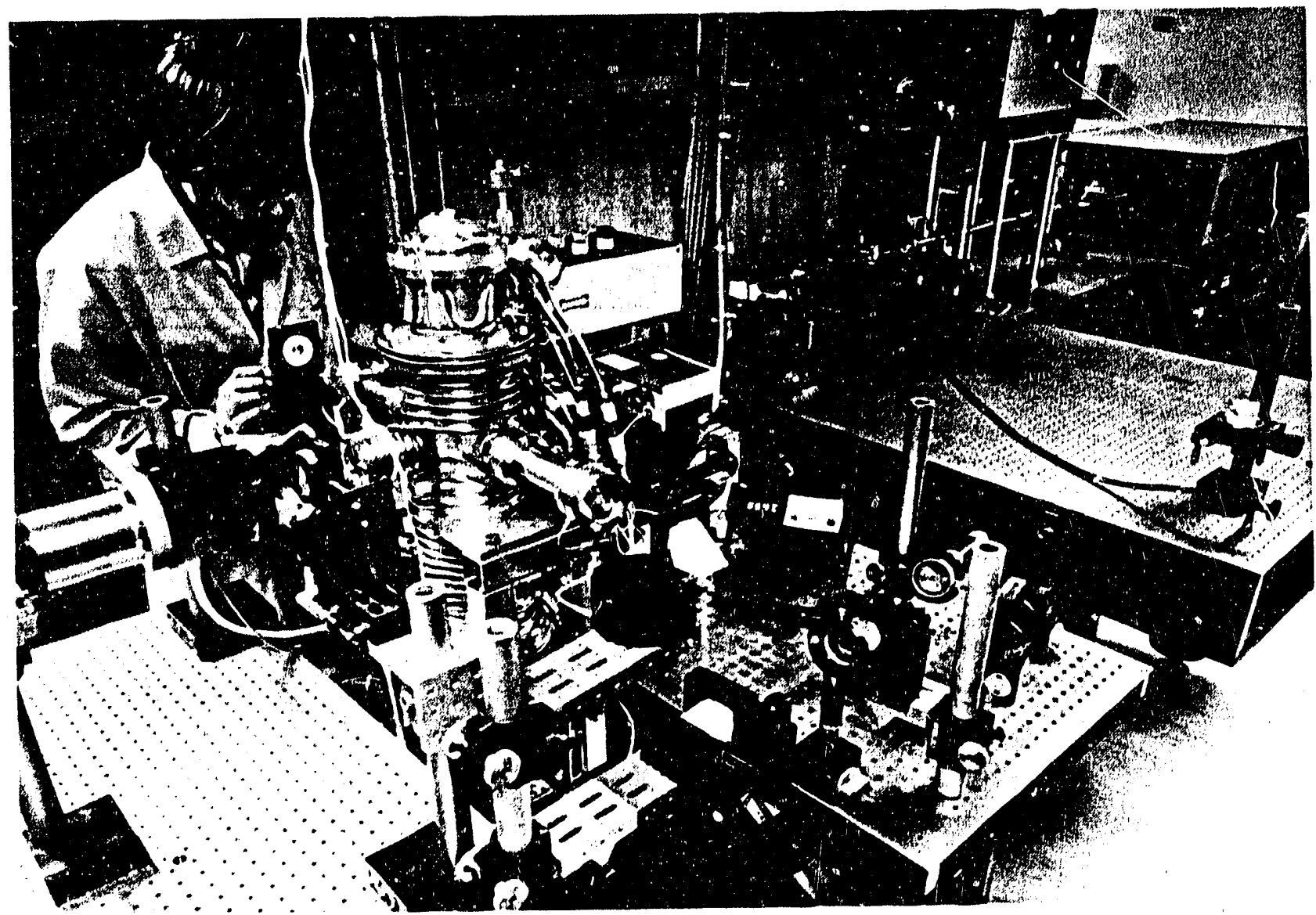

Figure 4. The Laboratory Arrangement of the Photofragment Eluorescence Spectroscopy Sor Alkali Detection

blades, which limits the life of a turbine (Bedick 1989). particles can also decrease efficiency because of deposition on turbine blades. In addition, smaller particles follow the gas flow, pass through the turbine and can be emitted to the atmosphere as a pollutant. Most advanced particle-control devices being developed are for the secondary or tertiary stages of particle control. Typically, cyclones are used for the primary particle control. Also, in situ cleanup techniques may involve injection of particles (dolomite) into the process that would then be used to capture undesirable species (such as sulfur compounds). Thus, particle characterization can improve capture efficienzy methodologies.

The following are the I\&D Projects for developing particle characterization techniques.

In situ Real-Time Analysis of Particles (Sandia National Laboratories) - The purpose is to develop optical diagnostic techniques to measure particle composition, size, and velocity in combustion environments. 
Laser spark spectroscopy is a variation of conventional emission spectroscopy, which uses a focused, pulsed laser beam to generate an optical breakdown, commonly called laser spark or laser-induced plasma. Figure 5 shows a diagram of the laser spark spectroscopy in a laboratory setup. A syringe-type particle feeder injects entrained coal particles along the vertical centex line of a premixed flat flame burner. Collinear, two-color Mie scattering determines the size and velocity. Light scattered by coal particles from a He-Ne laser beam is deflected

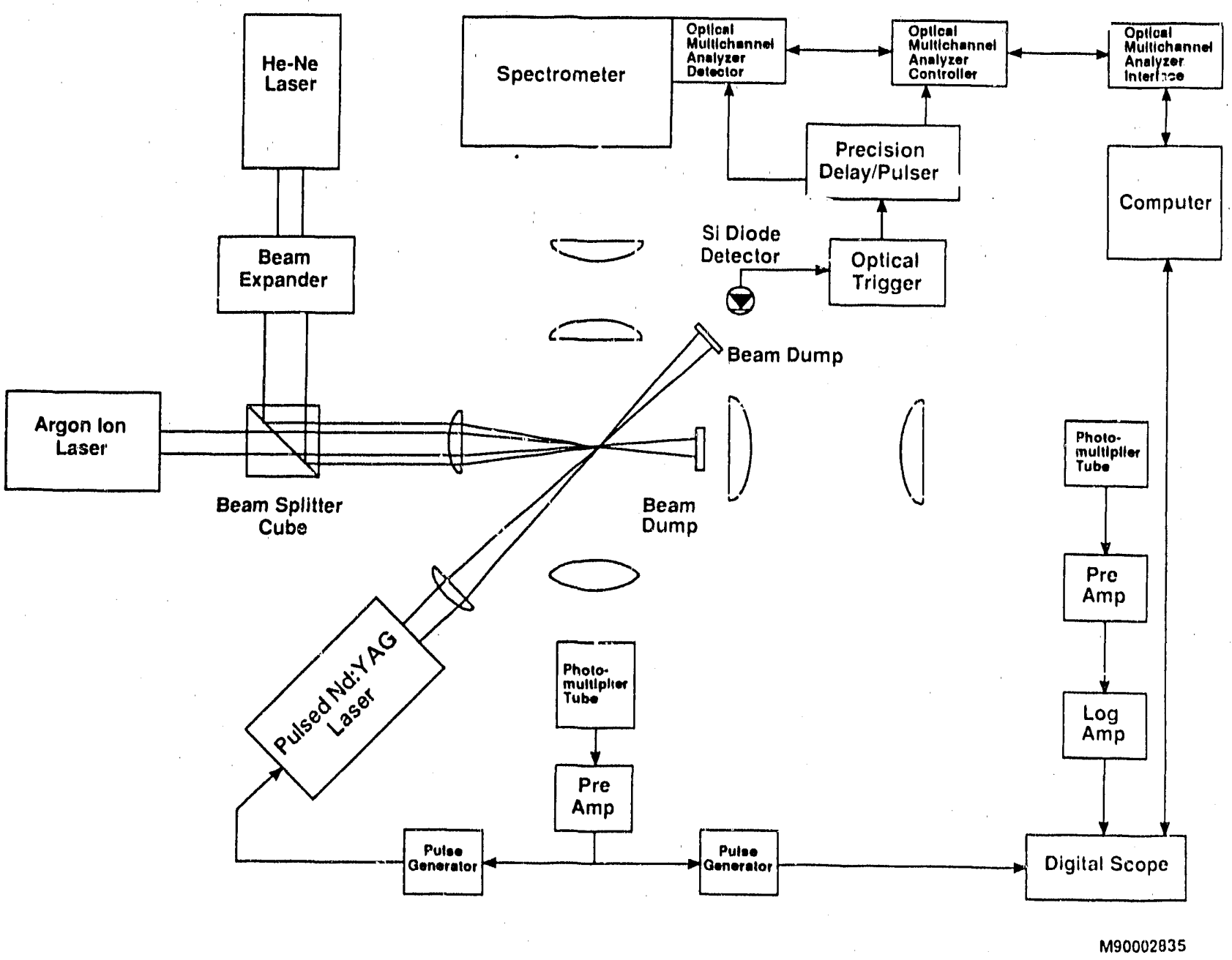

Figure 5. Laboratory Test Setup for Laser Spark Spectroscopy

at $90^{\circ}$ from the optical axis. This narrow focal waist measures only particles centered in the much broader argon ion laser beam. Scattered light from the argon ion laser beam is deflected in the near-forward direction. The scattered light from the He-Ne laser triggers a pulsed Nd:YAG laser. A last:r pulse from the Nd:YAG 
laser creates the plasma or spark at the particle. Iight emitted is collected and imaged on an entrance slit of a monochromator. A linear array detector is placed in the monochromator exit focal plane and measures the emission spectra.

The technique can simultaneously detect $\mathrm{C}, \mathrm{H}, \mathrm{O}, \mathrm{N}, \mathrm{Li}, \mathrm{Na}$, $\mathrm{K}, \mathrm{Mg}, \mathrm{Ca}, \mathrm{Ba}, \mathrm{Sr}, \mathrm{Al}, \mathrm{Ti}, \mathrm{Fe}, \mathrm{Mn}$, and Si. Practical detection limits for a single particle are less than 100 parts per million (ppm) by weight for most metals (Ottesen et al. 1988).

In situ Particle Characterization (The University of Tennessee Space Institutel -- The purpose is to develop software and circuitry for measuring the size of particles from laser Doppler velocimeter signals.

The basis of this technique is a commercial dual-beam laser Doppler velocimeter (LV). Using software and additional circuitry, particle size information can be obtained from the $\mathrm{LV}$ signals. The configuration of the particle size interferometer (PSI) consists of a linearly-polarized lasar source, a beam splitter, transmitting and receiving lenses, a photomultiplier tube, and a signal processor. Figure 6 shows the dual-beam laser Doppler velocimeter. The PSI splits the source laser beam into
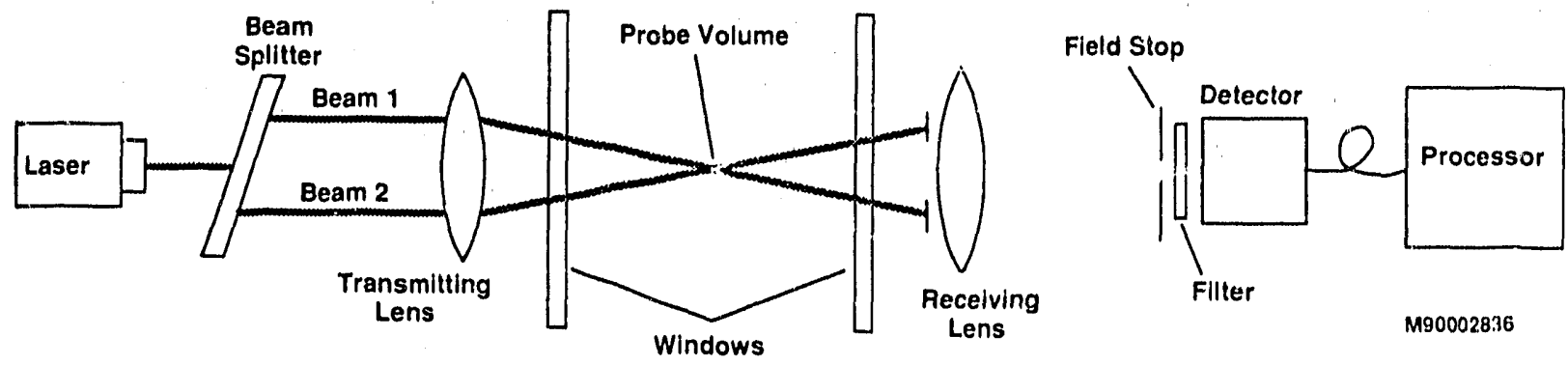

\section{Figure 6. Configuration of the Dual-Beam Laser Doppler Velocimeter}

two parallel and equal intensity beams. The focal volume is at the cross-over region of the beam. The probe volume can be viewed as a region of many uniformly spaced fringes. The receiving lens collects the scattered light from the particles passing through the probe volume and focuses the collected light at the photodetector. The signal from the photodetector is converted to particle velocity and size information.

Appraisal of the different characteristics of the LV signals provides particle size and particle velocity measurements simultaneously. Particles with diameters between 0.5 and $5.0 \mu \mathrm{m}$ have been investigated. LV light-scattering characteristics are 
complex and often non-monotonic functions of the particle size, index of refraction, laser light wavelength, laser intensity and polarization, and the characteristics of the detector. Although different components of the LV signal have been considered, this analysis concentrated on Doppler phase, visibility, and scatterintensity. No individual signal characteristic or optical configuration was found that would universally resolve size-signal relationship uncertainties. However, optimal configurations were identified for selected applications. (Giel and Son 1988).

Feasibility of Millimeter Wave Diagnostics for Coal Conversion and Combustion systems (Argonne National Laboratory) -- The use of millimeter wave (MMW) technique was explored for in situ diagnostics of particle-laden multiphase streams.

The intent was to determine if MMW can be used for molecular species identification, gas-phase or particle temperature measurement, or particle size and loading. In situ techniques depending on light are limited to streams with few particles. The light is absorbed by the particles reducing the output signals. The longer MMW should penetrate farther than optical techniques into particle laden streams.

Determining some major molecular species and gas-phase temperatures using MMW spectroscopy appears possible in atmospheric-pressure combustors. Particle temperature measurement using MMW radiometry appears likely. However, the particle concentration must be between $10^{8}$ to $10^{10}$ particles $/ \mathrm{m}^{3}$ of nominally $100 \mu \mathrm{m}$ particles. Determining particle size, size distribution, and loading appears possible when the particle concentration is low (Gopalsami and Raptis 1986).

\subsection{Thermophysical properties}

Advanced conversion systems require the measurement of thermophysical properties of gases, liquids, solids, and multiphase mixtures of each. These properties need to be measured to understand and predict events in a FE process, as well as to design future processes. The thermophysical properties that are being investigated include temperature, strain, viscosity, and deposition.

\subsubsection{Temperature}

Temperature is an important measurement since it is an indication of the operating state of a system. For example, temporal and spatial temperature measurements are essential to understanding chemical kinetics. In acidicion, temperature measurements can indicate heat transfer, corrosion, slagging, and 
fouling rates. Most processes require temperature monitoring for safety.

Selection of a temperature sensor includes considerations of cost, accuracy, measurement range, response time, size, and maintenance. The difficulties imposed on sensors in FE processes incilude operation under HTHE conditions, exposure to erosive particles, and variations in process flow patterns. Currently, thermocouples are the sensors used most often for measurement of temperature. However, alternate temperature measurement techniques are being develofied because of the limitations of thermocouples. For example, the thermocouple has a short life expectancy if not protected from erosion. Response time is slow and heat losses are high when a thermocouple is covered by a protective sheath. Other methods of temperature measurement include optical pyrometers, infrared cameras, thermistors, and resistance temperature detectors.

Several advanced optical diagnostic methods are being developed to meet the special requirements imposed on temperature monitoring in FE processes. The optical methods avoid many of the prob?ems associated with the severe conditions of FE processes. For example, measurements can be made in situ from the light absorbed or emitted from a process stream without intrusive probes. Fiber optics also minimize heat losses and offer the capability of high speed data transmission. Major limitations of optical technlques are gaining optical access and penetrating into particle-dense streams. The optical access must transfer the proper light entrgy to the signal processor.

The following are the I 4 D Projects for developing temperature measurement techniques.

High-Temperature Fluorescence Thermometry system (FTS) (Morgantown Energy Technology Center) -- The purpose is to accurately measure temperatuxes in combustion and gasification environments.

The FTS is an in situ optical sensing device designed to monitor the temperature of a process stream in near real-time. The FTS is based on the temperature dependent fluorescence decay characteristics of a crystalline sensor synthesized on the end of a sapphire rod. The fluorescenre decay time constant is a function of the fluorescent material and sensor temperature. The fluorescence based sensor is immune to electrical noise and insensitivity to variations caused by fiber microbending or changes material emissivities. The Nd:YAG sensor is excited via a pulse from a solid state laser diode whose wavelength falls within the absorption band of the fluorescent crystal. By calculating fluorescence $g$ rowth and decay, the temperature can be determined from measuring a time constant. Thermometry is 
insensitive to amplitude variations, optical attenuations, electrical interferences, and emissivities. A simplified schematic of the fluorescence thermometry technique is shown in Figure 7. This device will be field tested in product gas streams at the Texaco entrained-bed gasification facility. For this testing, two probes were calibrated over the temperature

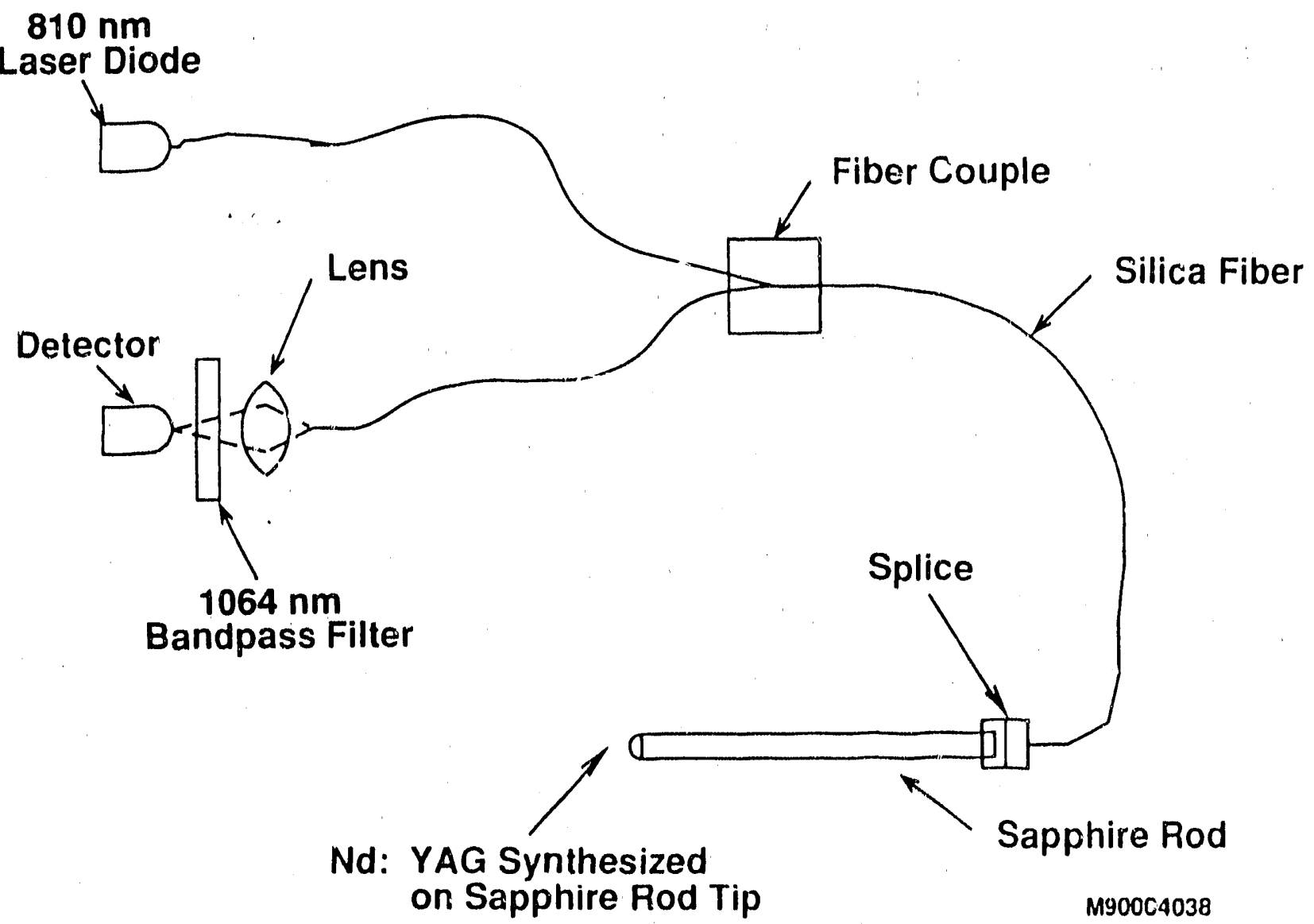

\section{Eigure 7. A Simplified Schematic of the Fluorescence Thermometry Technique}

range of 975 to $1,300 \mathrm{~K}$. The expected operating temperature will vary from 1,150 to $1,280 \mathrm{~K}$. (Shifflett 1989).

Nonisothermal pyrometry techniques were investigated in another METC effort. In many FE processes, the only means by which nonintrusive, in situ temperature measurements can be made 
is through the use of optical techniques. Pyrometry is one such technique. Conventional pyrumetric techniques require isothermal targets (sites for temperature measurement). FE processes often do not have isothermal targets, thus nonisothermal techniques are needed. Eight different pyrometers were evaluated to determine their response to norisothermal targets. The targets had two or mo:e temperature modes, where a mode represented an isothermal section of the target. The effect of varying emissivity was explored using computer simulations of the different techniques and targets. As a result, three nonisothermal pyrometry techniques were proposed: the changed single-color technique, the changed two-color technique, and the two-single-color technique (Hensel 1988).

An Investigation of Nonintrusive Radiometers for Entrained-Bed Gasifier Temperature Measurement ('TRW) -- The sodium line emission pyrometer (SLEP) was used to measure temperatures in a coal combustor.

Theoretical considerations of the $\mathrm{Na}$ emission intensity in typical coal conversion facilities have shown a way to exploit this emission for temperature measurement. The $\mathrm{Na}$ is typically in thermodynamic equilibrium vith the gas and the measurements, therefore, yield gas temperatures. The implementation of the SLEP requires an optical access port. This was provided by an aerodynamic window, which consists of a pinhole and a set of transfer lenses. The pyrometer utilizes a fiber optic cable to transfer the collected emission, a high-resolution echelle spectrometer, a linear detector array, and an optical multichannel analyzer. SLEP compares the intensity of the sodium emission with the Planck' $s$ blackbody finction to compute the gas temperature. The SLEP was tested on 'IRW' $s$ coal combustor. The measurement accuracy was only limited to the noise in the electronic detection system. Temperatures between 1,700 and 2,000 $\mathrm{K}$ with an accuracy of $\pm 10 \mathrm{~K}$ were measured. (Fairchild 1985).

\subsubsection{Strain}

Another property being measured is strain (i.e., material displacement under load). In situ strain measurements play an important role in validating the structural analysis predicted by models. Finite element models can be used to predict maximum strain and stress at various mechanical loads (e.g., vibrations, clamping forces, differences in thermal expansions, and pressures) and material properties (e.g., yield strength, thermal conductivity, modulus of elasticity, and coefficient of thermal expansion). The models can predict whether or not a component can survive the mechanical loading. 
The following is the I\&D Project for developing strain measurement techniques.

Smart structures for Eossjl Energy Apolications jVirginia Tech Universityl - The goal of the project is to measure in situ strain of coramic cross-flow filters.

Sensing devices based on fiber optics offer many advantages. They are thin, flexible, and immune to electromagnetic interference. The fibers can be coated to protect the optical fibers from the harsh FE process conditions. The term "smart" crossflow filters refers to various fiber optic sensing systems that can be attached to a ceramic filte to sense strain levels, temperature, ard dust-cake buildup. Ceramic cross-flow filters are used to remove particles from HTHP process gas streams (Bossart 1989). The sensors can also be instajled as an integral. part of the ceramic barrier (cross-flow) filters. Information: collected by the smart structure system can be used to identify weak areas of the filter. This information can be used to improve the design of the filter. Smart cross-flow filters incorporate clad and coated sapphire optical fibers as the sensing elements. Possible claddings and coatings have been identified for sapphire fibers. Cladding materials successfully used are $\mathrm{SiO}_{2}, \mathrm{Al}_{6} \mathrm{Si}_{2} \mathrm{O}_{13}$, and $\mathrm{SiO}_{4} \mathrm{~N}_{4}$. The cladding causes a difference in the index of refraction that should lessen the light attenuation. Coating materials that have been considered are $\mathrm{Ta}_{2} \mathrm{O}_{5}, \mathrm{TiO}_{2}, \mathrm{Al}_{6} \mathrm{Si}_{2} \mathrm{O}_{23}$, and $\mathrm{ZrO}_{2}$. The coatings must have the strength and durability to protect the sapphire.

Successful tests of a smart cross-flo\% filter were completed in the Westinghouse bench-scale PFB combustor simulator. The smart cross-flow filter used an in-line, intensity-based sensor and a Fabry-perot optical fiber sensor. Figure 8 shows an experimental setup for the test of multiple fiber optic air-gap strain sensors. This initial test used silica optical fibers instead of sapphire. The intensity-based sensor uses an air-gap splice. Strain is derived from changes in the splice length, which causes a proportional change in the light intensity. The Fabry-Perot interferometer measures reflection at the glass-air interface. A diffraction pattern forms from the reflections at each side of the glass and fiber interfaces (Claus et al. 1989; Mu'phy et al. No date).

\subsection{3 viscosity}

Viscosity is a measurement of a fluid's resistance to flow. It has a direct impact on the power required for moving the fluid (i.e., the pumping requirements). Viscosity affects the operation of nozzles and atomizers. It is difficult to determine 
viscosity in FE processes because the fluids are generally multiphase and non-Newtonian (not Iinear with shear rate).

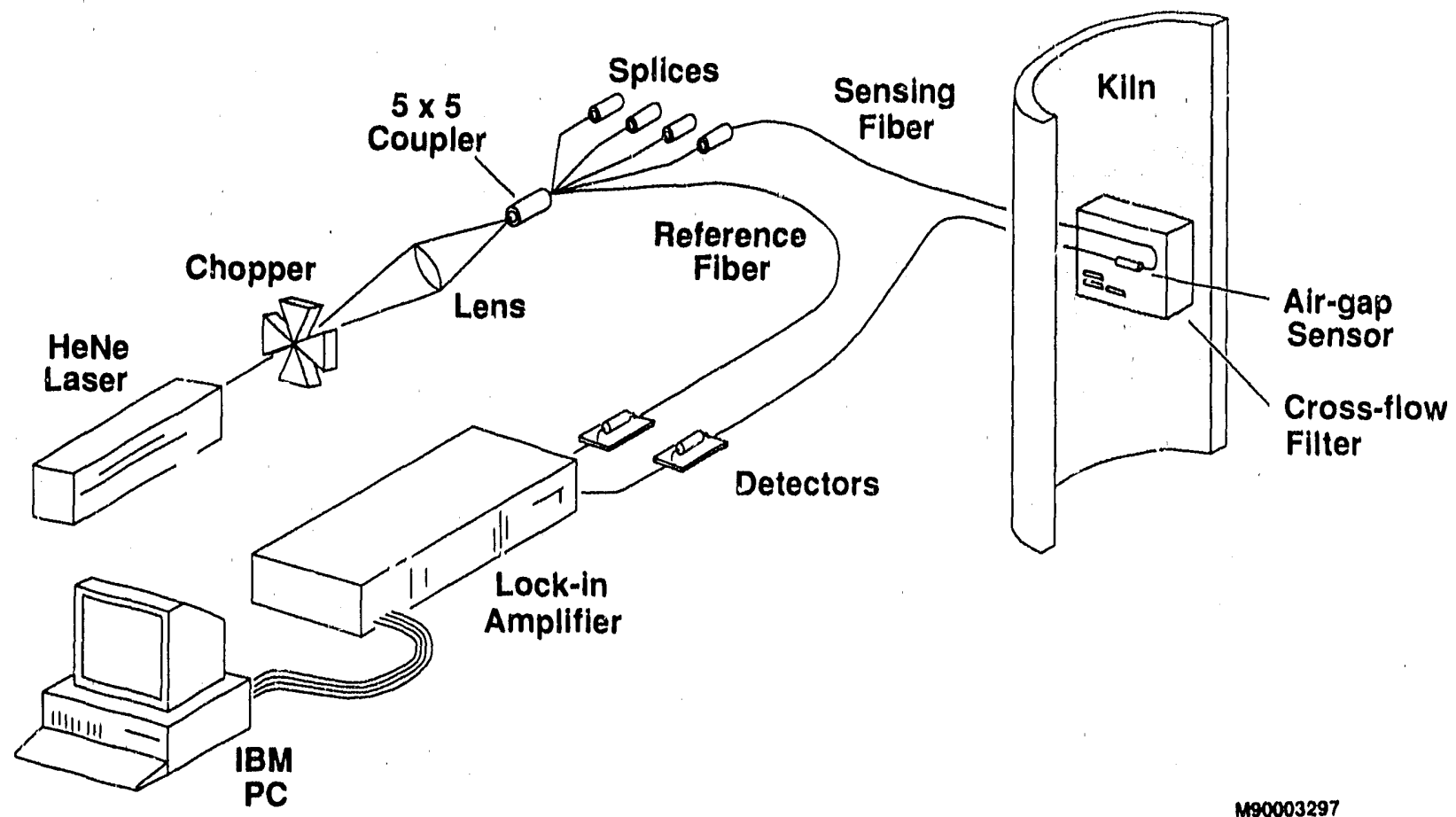

Figure 8. Experimental setup for Testing Multiple siber Optic Air-Gap Strain Sensors

The following is the I\&D Project for developing viscosity measurement techniques.

A Feasibility Study on Advanced Techniques for On-Line Monitoring of Coal Slurry Viscosity (Argonne National Laboratory) -- The purpose of this project is to survey available coal-siurry rheological data and to evaluate an ultrasonic method for measuring slurry viscosity.

Viscosity measurement techniques can be classified into three principal methodologies: mechanical, ultrasonic, and electromagnetic. Mechanical viscometers have been on the market for a long time, but have only recently been used for nonNewtonian fluid characterization. Ultrasonic viscometers have good potential for development as on-line monitors. Industrial application of electromagnetic methods is unlikely, but electromagnetic methods have been used in basic research. 
The ultrasonic method used for measuring slurry viscosity was based on acorstic attenuation. It is desirable for viscosity measurements to be a function of ultrasonic frequency and change over a range of coal concentrations. This method involved the correlation of acoustic viscosity, a sum of shear waves, and bulk viscosity. An acoustical wedge was constructed of aluminum and was attached to the slurry piping. The acoustical wedge is shown in Figure 9. The air and wedge interface provided the reference refiected signal. The shear wave reflected from the air interface remained constant. The shear wave from the wedge measured the viscosity of the boundary layer liquid just inside the pipe. This technique was not useful in determining the viscosity of the bulk slurry. The boundary layer viscosity needs to be correlated with the actual slurry viscosity (Sheen and Raptis 1987).

\subsubsection{Deposition}

Particles can decrease system efficiency by depositing on turbine blades and causing an increased flow resistance. Deposition problems are caused primarily by the mineral matter in coal and its behavior after combustion. Methods were investigated to measure deposition rates to examine factors controlling deposit formation. Particle adherence to surfaces is mainly a function of particle size, particle composition, particle velocity, angle of incidence, surface composition, and the temperatures of the gas, particle, and surface (METC 1985).

The following is the Instrumentation and Dlagnostic Project for developing deposition measurement techniques.

Ash Deposition Sensor Development (Morgantown Energy Technology Center) -- Deposition sensors and deposition rate sensors capab.le of in situ, real-time measurement in FE streams will be developed in this project.

Three types of deposition measurement sensors have been developed: a heat flux sensor for coal-water fueled combustors, a dual-pendulum prototype deposition sensor, and a surface acoustic wave technique. The prototype heat flux sensor was a simple, rugged, low-cost unit, with high sensitivity. It could operate in high pressure under highly corrosive conditions. However, the sensor was somewhat limited in high-temperature applications, because of its sensitivity to thermal radiation and loss of heat through the sides of the sensor (Sun and Bajura 1985).

A dual-pendulum deposition sensor was used to monitor deposit formation. It had the same temperature limitations of the heat flux sensor and about the same degree of accuracy. However, the dual-pendulum sensor was more intrusive. It required more costly supporting electronics, was less rugged, and weis more 
subject to mechanical and electrical interference than the heat flux unit.

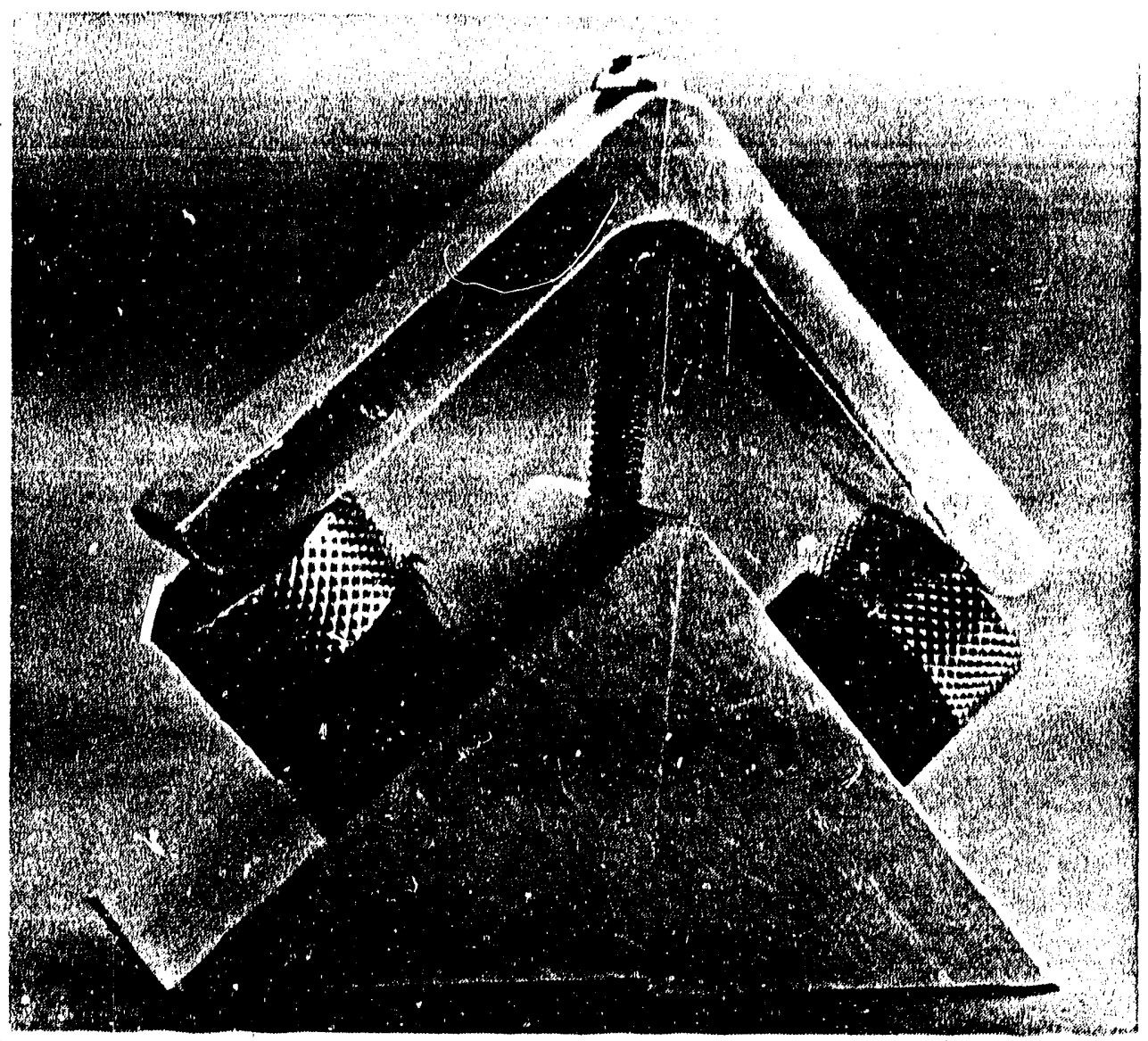

Eigure 9. Aluminum Acoustical Wedge Used to
Determine Slurry Viscosity

The surface acoustic wave technique was restricted to low temperature applications. However, it was a rugged, nonintrusive, and accurate sensor, although it required a great many costly electronic support systems (Fasching and Smith 1987).

\subsection{Procegs Control Systems}

The maturing of advanced coal-based technologies has motivated the development of process control systems. Sensory units provide input data for flexible, computerized process control systems with adaptive, decision-making capabilities. Directsynthesis controllers quantify process information in a systematic and relatively simple way. Adaptive direct-synthesis controllers improve control by adapting model parameters to measured process variables (Badavas 1984). 
Current emphasis has shifted from systems identification to expert control systems. During unplanned process interferences and emergencies, expert control schemes and smart sensors should provide optimal operation of coal-based technologies.

The following is the Instrumentation and Diagnostic Project for developing process control systems.

Process Control Expert Systems (Morgantown Energy Technolocy Center) -- The purpose of this project is to investigate artificial intelligence (AI) expert system techniques and advanced microprocessors for enhanced control of FE processes.

One expert system is used to position a particle in an electrodynamic balance by tuning the proportional and integral control parameters. This system was nonlinear in response to the controlled variable, and thus, a linear mathematical solution of the control parameters was impossible. Process changes occurred too quickly for control by manual tuning methods. A real-time, process simulation overcame these problems. The expert system ran concurrently with this simulation and tuned the control parameters to satisfy the stability criterion. These parameters were incorporated into the control system to set proper control stability, overshoot, and settling time. The process operation could be standardized and repeated because of the expert system (Lawson et al. 1989).

An expert control system was also designed earlier to determine the bed level of a fixed-bed gasifier system by sequencing coal feed and ash removal. However, the expert system was not tested since the gasifier became non-operational (Keech 1988). In addition, it was impractical to reprogram the existing system for each different operating procedure or bed characteristic. In expert syste: technique could provide the flexibility to change the operating constraints of the monitor without reprogramming.

\subsection{Multiphase Elow Charactexization}

Many advanced coal-based technologies require the movement of solids (e.g., coal feed and ash removal) in their processes. Accurate mass flowrate measurements are necessary for on-Iine control of the movement of solids in FE process. Most conventional mass flowrate techniques penetrate the process stream. Non-intrusive mass flowrate methods are being investigated to eliminate blockage or impedance of flow by the controliing device. Nonintrusive mass flow measurements also avoid erosion from the solids.

Many of these processes transport coal with a carrier gas or liquid. Thus, the process streams that contain both solids and 
fluids are called multiphase flow. Multiphase flow streams are difficult to characterize because the flowrate is non-linear with the shear rate (i.e., a non-Newtonian fluid).

Proper coal feed rates can prevent explosions in ertrained flow gasifiers and pulverized soal combustors that use dry coal. feed systems. Explosions can occur at high temperatures when there is an intermittent loss of coal feed, but the oxidant continues to flow to the gasifier. Less abrupt coal feed changes without corresponding adjustments to the oxidant flow can cause fluctuations in reactor temperature. These thermal fluctuations over-stress refractory linings or metal shells, which lowers the vessel life.

The following is the Instrumentation and Diagnostic Project for developing multiphase flow characterization techniques.

Capacitance Elowmeter (Argonne National Laboratory) -- The purpose was to measure the solid feed rate in a coal gasification plant's gas-solid feed, interstage, ad recycling lines.

The basis of the capacitance flowmeter technique is measurement of the frequency and amplitude of capacitance noise. In an experiment, two flowmeters were installed in the horizontal leg of the piping test loop located at Argonne. In one capacitance flowmetex, electrodes were protruded through the pipe's ceramic liner to determine the solid component flowrate. The second flowmeter used a densitometer with electrodes flush with the pipe's interior surface. This flowmeter determined the solid volume fraction. Only the solid-component intrinsic density, tho dielectric constant, and the duct cross-sectional area were needed to determine the solid flowrate. Short-lived radioactive particles were used to calibrate particle velocities.

In another experinent, the performance of a capacitive flowmeter was experimertally tested in a gas-entrained solid flow stream. The solid feedrates were varied from 0.5 to $2 \mathrm{~kg} / \mathrm{s}$ with solid volume fractions extending from 0.004 to 0.016 . Based on test results, the capacitive sensors should provide a reliable means of determining mass flowrate, the solid volume fraction, and particle velocities (Bobis et al. 1986). 


\section{0 CONCLUSION}

Instrumentation needs usually evolve from a desire to measure or control critical parameters to improve effectiveness, operability, reliability, or safety of a system. Often off-theshelf commercial instruments and diagnostics require adaptation to operate in FE processes. Development activities performed in the AR\&TD I\&D Program are intended to support all FE processes. The activities involve the determination of the theoretical, analytical, and experimental feasibility of instrumentation and diagnostic devices and techniques.

AR\&TD instrumentation and diagnostics techniques need to consider the working environments of FE processes. Coal-based process streams are often HTHP and include corrosive compounds and erosive particles. Real-time measurements are needed to adjust to rapidly changing conditions. Nonintrusive measurements are desirable to avoid eroding of the sensors or blocking the streams. In situ measurements eliminate problems of extractive sampling methods. Instrumentation requirements are more demanding during process development than during commercial operation of a plant, because operating limits have not been established for when a process is under development. Operating limits provide design criteria to scale systems at a minimum cost.

I\&D is an integral part of the development of advanced coalbased technologies. The purpose of I\&D is to provide information that can be used to increase system efficiencies, reduce operating and capital costs, minimize waste disposal, and reduce pol-lutant release into the environment. Improved FE instrumentation and diagnostics is necessary to achieve commercialization of advanced coal-based processes. 


\subsection{ABBREVIATIONS AND ACRONYMS}

$\begin{array}{ll}\text { AI } & \text { Artificial intelligence } \\ \text { ARETD } & \text { Advanced research and technology development } \\ \text { DOE } & \text { U.S. Department of Energy } \\ \text { FE } & \text { Fossil Energy } \\ \text { FTS } & \text { Fluorescence Thermometry system } \\ \text { HTHP } & \text { High-temperature, high-pressure } \\ \text { I\&D } & \text { Instrumentation and diagnostics } \\ \text { ICP } & \text { Inductively coupled plasma } \\ \text { IGCC } & \text { Integrated gasification combined-cycle } \\ \text { LED } & \text { Iight emitting diode } \\ \text { LIBS } & \text { Laser-induced breakdown spectroscopy } \\ \text { LSS } & \text { Laser spark spectroscopy } \\ \text { LV } & \text { Laser Doppler velocimeter } \\ \text { METC } & \text { Morgantown Energy Technology Center } \\ \text { MMW } & \text { Milimeter wave } \\ \text { MOS } & \text { Metal oxide semiconductor } \\ \text { Nd:YAG } & \text { Neodymium-doped yttrium aluminum garnet } \\ \text { PFB } & \text { Pressurized fluidized-bed } \\ \text { PPb } & \text { Parts per bilion } \\ \text { PPm } & \text { Parts per milion } \\ \text { PPt } & \text { Parts per trillion } \\ \text { PSI } & \text { Particle size interferometer } \\ \text { SLEP } & \text { Sodium line emission pyrometer }\end{array}$




\section{0 REFERENCES}

Badavas, P.C. 1984. Direct-Synthesis and Adaptive Controls. Chemical Engineering February 6: 99-103.

Bedick, R.C. 1989. High-Temperature Contaminant Control for CoalBased Gas Turbine systems. International specialty conference on Combustion and the Environment. Seattle, washington. March 8-10.

Bobis, J.P., K.G.A. Porges, A.C. Raptis, W.E. Brewer, and L.T. Bernovich. August 1986. Particle Velocity and Solid Volume Fraction Measurements with a New Capacitive Flowmeter at the Solid/Gas Elow Test Facility. Argonne National Laboratory ANL/FE-86-4.

Bossart, S.J. 1989, Adranced Particle Control Technologies for Pressurized Fluidized-Bed Combustion Applications. 51st Annual American Power Conference. Electric Power Research Institute. Palo Alto, California. April 24-26.

Chisholm, W.P. October 1989. On-Line Compositional Detection Techniques. In Proceedings of the Advanced Research and Technology Development Direct Utilization. Instrumentation and Diagnostics Contraciors Review Meeting. DOE/METC-89/6108, Vols. 1 and 2. NTIS/DE9000424.

Claus R.O., S.B. Desu, and K.D Bennett, W.P. October 1989 . Smart Structures for Fossil Energy Applications. In Proceedings of the Advanced Research and Technology Development Direct Utilization, Instrumentation and Diagnostics Contractors Review Meeting. DOE/METC-89/6108, Vols. 1 and 2 . NTIS/DE9000424.

Elliott, M.A., Ed. 1981. Chemistry of Coal Utilization, Second Supplementary Volume. New York: John Wiley \& Sons.

Fairchild, 2.W. March 1985. An Investigation of Nonintrusive Radiometers for Entrained Gasifier Temperature Measurement. $\mathrm{DOE} / \mathrm{MC} / 20468-1842$.

Fasching, G.E., and N.S. Smith. October 1987. Surface Acoustic Wave Deposition Sensor. DOE/METC-87/4074. NTIS/DE87006527.

Giel, T.V., and J-Y. Son. June 1988. Particle Sizing Experiments with the Laser Doppler Velocimeter - Final Report. DOE/MC/22184-2661. NTIS/DE89000910. 
Geiling, D.W., and P.M. Goldberg. October 1989. Proceedings of the Advanced Research and Technology Development Direct Utilization, Instrumentation and Diagnostics Contractors Review Meeting. DOE/METC-89/6108, Vols. 1 and 2. NTIS/DE90000425.

Gopalsami, N., and A.C. Raptis. June 1986. Eeasibility of Millimeter Wave Diagnostics for Coal Conversion and Combustion System. Argonne National Laboratory. ANL/FE-86-2.

Hardesty, D.R., Ed. August 1984. An Assesgment of Optical Diagnostics for In Situ Measurements in High Temperature Coal Combustion and Conversion Flows. Sandia National Laboratory. SAND 84-8724.

Haran, M. February 1986. The Instrumentation Sourcebook: A Compendium of Instruments and Techniques for Energy Research. prepared by DHR, MCLean, Virginia.

Hensel, J.P. March 1988. Nonisothermal Pyrometry Technique -Research Report. DOE/METC-88/2029. NTIS/DE88010282.

Hickerson, J.D., ed. September 1988. Advanced Research and Technology Development (AR\&TD) Direct Utilization and Instrumentation and Diagnostics Contractors' Review Meeting. Conf-8809162. NTIS/DE89007029.

Holcombe, N.T., ed. October 1987. Proceedings of the ARETD Direct Utilization, and Instrumentation and Diagnostics Contractorg Review Meeting. DOE/METC-88/6084, Vols. I and II. NTIS/DE88001002.

Hubbard, C.W. and R.I. Gordon. May 1987. Chemical Sensors. Pacific Northwest Laboratory. PNL-6151

Keech, T.W. Jr. October 1988. Instrumentation Development for the METC 42-Inch Stirred, Fixed-Bed Coal Gasifier Final 'Technical Report. DOE/METC-89/2030. NTIS/DE89000902.

Lawson, L.O., J.P. Hensel, J.D. Thornton, B. Solheim, D.M. Henry. october 1989. Artificial Intelligence in Process Control. In proceedings of the Advanced Research and Technology Development Direct Utilization, Instrumentation and Diagnostics Contractors Review Meeting. DOE/METC-89/6108, Vols. 1 and 2 . NTIS/DE9000424.

Liptak, B.G., and C.P. Leiter. May 1980. Overview of Coal Conversion Process Instrumentation. Argonne National Laboratory Technical Memorandum No. 1 (ANL-FE-49628-TM01). 
Mattox, D.M. June 1985. Investigation of Semiconductor Gas Sensing Devices for Coal Gasification Process Streams. DOE/MC/21021-2024. NTIS/DE86005463.

METC. Hugust 1985. Systems Studies and Combustion Research for Coal-Fueled Heat Engines - Technology status Report. DOE/ METC-86/0240. NTIS/DE96006616.

Murphy, K.A., M.S. Miller, C.E. Koob, and R.O. Claus. No date. optical Fiber Extrinsic Fabry-Perot Sensors. Optical Fiber EFPI Sensorg. Photo Technical Letters.

Nelson, E.T., W.H. Fischer, J.V. Lipka, M.D. Rutkowki, and R. Zaharchuk. nctober 1987. Assessment of instrumentation needs for advanced coal power plant applications: Final Report. Gilbert/Commonwealth Associates. DOE/MC/23088-2532. NTIS/DE88001030.

O'Fallon, N.M., R.A. Beyerlein, W.W. Managan, H.B. Karplus, and T.P. Mulcahey. January 1976. A Study of the State-of-The-Art of Instrumentation for erocess Control and Safety in LargeScale Coal Gasification, Liquefaction, and Eluidized-Bed Combustion systems. Argonne National Laboratory. ANL-76-4.

Oldenborg, R.C. October 1989. Optical Detection of Corrosive Compounds. In Proceedings of the Advanced Research and Technology Development Direct Utilization, Instrumentation and Diagnostics Contractors Review Meeting. DOE/METC-89/6108, Vols. 1 and 2. NTIS/DE9000424.

ottesen, D.K., J.C F. Wang, L.J. Radziemski. June 1988. RealTime Laser Spark Spectroscopy of Particulates in Combustion Environments. Sandia National Laboratories. SAND88-8862.

Romanosky, R.R., L. MCCarty, and W. Chisholm. 1989. An Argon/ Helium ICP for Determination of Trace Metals in Fossil FuelDerived Process Gas Steams. Proceedings from Pittaburgh Conference on Analytical Chemistry and Applied spectroscopy. Atlanta, Georgia. March 6-10.

Sheen, S.H., and A.C. Raptis. October 1987. A Eeagibility Study on Advanced Techniques for on-Line Monitoring of Coal siurry Viscosity. Argonne National Laboratory. ANI/FE-87-8.

Shifflett, P. Cctober 1989. High Temperature Fluorescence Thermometry. In Proceedings of the Advanced Research and Technology Development Direct Utilization, Instrumentation and Diagnostics Contractors Review Meeting. DOE/METC-89/6108, Vols. 1 and 2. NTIS/DE9000424. 
Sun, Y. Z., and R.A. Bajura. June 1985. Deposition Rate Sensor Development Project - Final Report. DOE/MC/20208-2098. NTIS/DE86004816. 


\section{ARPENDIX A}

The Fossil Fuel Instrumentation Research Database system (FFIRDS) is a consolidated system that organizes, files, and retrieves $F E$ instrumentation and diagnostics information. Appendix A lists abstracts by author in the database as of July, 1990. The FFIRDS has an advantage over typical library instrumentation databases, since it contains instrumentation developments that were started as part of the development of advanced coal-based technologies. Instrumentation development tends to be less documented and published when it is part of a larger development project for advanced coal-based technologies.

EFIRDS is menu-driven and relatively user-friendly. It uses both dBase III plus and WordPerfect for data entry, storage, retrieval, sorting, and creation of reports. The information for project reports is organized into EEIRDS by these fields: Title, Technology Area, Process Area, Authors, Address of Performing Organization, Phone Number, Contract Number, Date of Report, and Abstract. The technology areas are Multiphase Flow, Chemical Composition, Temperature Measurement, Thermophysical properties, Particle Characterization, Process Control, Nondestructive Testing, and General. The process areas are Gasification, Liquefaction, Combustion, Heat Engines, Heat Recovery, Fuel Cells, Cleanup Control, and Coal Preparation. 
Aakerhielm, F., G.G. Bergdahl, and A. Johansson, "Fluidized Bed Sensor Signals Analysed by Means of Nolse Techniques."

Ali, M.S., "In-Situ EPR Studies of Coal Pyrolysis."

Allendorf, M.D., and R.E. Palmer, "Spontaneous Raman spectroscopy in Flanes Containing High Concentrations of Silica Particles."

Asakura, M., T. Kawanabe, N. Kushida, and H. Hasebe, "Oxygen Concentration Sensing Device for an Air-Fuel Ratio Control system of an Automotive Internal Combustion Engine."

Assa, A.S., and S.R. Mannara, "Laser Doppler Vibration Testing."

Assenmacher, P., E. von Beeren, and K. Kloehr, "Primary Measures for the No Reduction at a Gas Boiler (235NW). Measuring Results and Opsrating Experiences."

Ayat, G., "Development of a Technique for Rapid Efficiency Determination of Coal Cleaning Devices."

Baker, E.G., G.L. Roberts, and I.K. Mudge, "Ammonia Removal in Coal Gasification Processes by Adsorption on Zeolites: Final Report."

Baky, B.I., and R.B. Hammond, "An Automated Two-Dimensional Laser velocimeter system."

Baughcum, S.I., R.C. Oldenborg, and D.J. Taylor; K.E. Apt, Ed., "Laser-Based Diagnostics for Coal Gasification Instrumentation."

Baxter, L.I., T.H. Fletcher, and D.K. Ottesen, "Spectral Emittance Measurements of Coal Particles."

Bek, A., J. Mierzwinski, and J. zielinski, "Development of Systems for Technological Process Control, Signaliing and Automation in Coal Preparation Plants."

Belford, R.L., "Electron Spin Mapping of Coal Molecular structure by ENDOR (Electron-Nuclear Double Resonance)."

Berkhahn, W., and E. Wiedeking, "IR Spectroscopic Measurements of HCL in Flue Gas Using the 677 IR HCL-Measuring System." 
Bertollini, G.P., L.M. Oberdier, and Y.H. Lee, "Image Processing System to Analyze Droplet Distribution in Sprays."

Bieber, M., and S. Wandel, "Oxygen Concentration Measurements by Solid Electrolytes Within Coal-Fired Fluidized Beds."

Blechinger, C.J., and S.I. McCarthy, "Mass Atrflow Meter."

Bobis, J.R., K.G.A. Porges, A.C. Raptis, W.E. Brewer, and I.T. Bernovioh, "Particle velocity and solid volume fraction with a New Capacitive Flow Meter at the Solid/Gas Flow Test Facility."

Bolcek, R., H. Mann, P. Minak, and M. Streicher, "Problems of Dimensioning Cycloniz Separators of Gas-Cileaning and SolidsRemoval systems for Conditions of Pulverixed Fuel Gasification Equipment."

Bosold, R.C., and D.M. Glessner, "Laboratory Guidelines and Procedures for Coal Analysis: Volume 1, Assessing the Cleanability of Eine Coal."

Brasher, W.D., and P.T. Carpentier, "Sampling system Monitor."

Brennan, B.W., W.B. Spillman, Jr., and J.R. Lord, "Embedded Fiber Optic Acoustic Sensor for Composite Materials."

Brueggemann, D., E. Hassel, and G. Littie, "CARS Measurements Performed on a Series Otto-Engine."

Bulanov, E.A., and I.A. Zinov' eva, "Chromatography Method for Determining Composition of Coal Gas and Blast Furnace Gas."

Elnker, B.C., D.R. Tallant, C.H.F. Peden, S.I. Martinez, and G.I. Turner, "Raman and NMR Studies of Hydrous Sodium Titanates."

Burchill, P., B. Dunstan, C.A. Mitchell, and T.G. Martin, "SolidState Techniques for Coal Characterization. In: Round-Table Meeting, 'Chemical and Physical Valorization of Coal.'"

Butler, M.A., and D.S. Ginley, "Optical sensing of Chemically Induced Strains."

Campbell, C.S., "Fluidization Mechanisms in slurry Flows."

Casleton, K.H., J.P. Kanosky, and W.J. Case, "Laser Induced Fluorescence Detection of Mineral Vaporization Species." 
Chaparro, I.E'., "Automated Miorosoopy Methods for Measuring Pyritic Sulfur Content of Coal and Determining Degree of Liberation of Pyrite in Coal."

Chaparro, I.F., "Automated Microscopy Methods for Measuring Pyxitic Sulfur Content of Coal and Determining Degree of Liberation of Pyrite in Coal: Elnal Report"

Chehroudi, B., P. Lombardi, P.G. Felton, and F.V. Bracco, "Spray Photography and Measurements of Poppet Lift and Injection Pressure in an oscillating poppet. Injector."

Chess, E.K., H.T. Kalinoski, B.W. Wright, H.R. Udseth, and R.D. Smith, "Applications of Superoritical Fluid Chromatography-Mass Spectroscopy in the Alalysis of Fossil Fuels."

Chess, E.K., and R. Smith, "Development and Evaluation of Supercritical Fluid Chromatography-Mass Spectrometry."

Chisholm, W.P., "Laser-Induced Breakdown Spectroscopy (LIBS) for the Analysis of Fossil-Enexgy-Derived Process Streams."

Cole, D.J.r "Computer Control strategies for Optimal Engine Performance."

Conzemius, R.J., and G.A. Junk, "Time-of-Elight Mass spectrometry."

Crawford, R.W., T.T. Coburn, R.E. Miller, and M.S. Oh, "On-Iine Mass Spectrometric Determination of Ammonia from Oil Shale Pyrolysis Using Isobutane Chemioal Ionization."

Dawes, S.G., Director, "Grimethorpe PFBC Establishment, Research Instrumentation Development for Test Series A1 and A2 at the Grimethorpe PFBC Facility."

Daykin, K.W., G.S. Jones, and J.B. Smith, "The Accuracy of Sampling Product Streams."

De, S.K., "A Method of Rapid Determination of Moisture in Coal by Microwave Absorption."

Devins, D.W., "Economic Benefits of On-Line Analysis."

Divisek, J., "Electrochemical Gas Analyzer for $\mathrm{SO}_{2}$ Content in Gases, More Particularly Flue Gas."

Dodge, L.G., D.S. Moulton, and W.E. Likos, "Micronized Coal Powder and Coal Slurries: Preparation and Characterization." 
Draeger, J.A., "Laser-Based Infrared Spectroscopy for Trace Analysis of Process streams."

Duffy, D., and P.F. Wiggins, "Coal Analysis with Gamma-Rays from Capture of Californium-252 Neutrons: Experimental Designs and Results."

Dvorakova, V., "Research into Possibility of More Accurate Determitration of lotal Water Content of Reserves of III Ccal."

Eokert, C.A., "Superoritical Eluid Thermodynamios for Coal Processing."

Ellington, W.A., E. Segal, and M.W. Vannier, "X-ray Computed Tomography for Structural Ceramio Application: Beam Hardening Corrections."

Erken, A.M., "NH 3 Slip Monitoring, State and Development Trends of the Continuous $\mathrm{NH}_{3}$ Measuring Devices."

Ertekin, T., "New Strategies for In-Situ Characterization of Coal: Quarterly Report for the Period Cct. 1, 1987, through Dec. 31, 1987."

Esterl, J., T. Gozant, C. Spencer, M. Bernatowicz, S. Wolff, and M. Floyd, "Neutronic Mass Flow Rate Meter for Continuous MassFlow Rate Measurements: Second Phase: Final Report."

Fanglu, G., and L. Wenzhen, "Measurement and Study of Velocity Field in Various Cyclones by Use of Laser Doppler Anemometry."

Farber, M.S., V.M. Shmal'ko, V.I. Shustlkov, and M.G. Sklyar, "Investigating Interaction of Alpha-1 Fraction and the Remaining Pitch Components by Means of Electron Spin Resonance"

Fasching, G.E., L.O. Lawson, and J.P. Hensel, "AR\&TD Instrumentation Development."

Fasching, G.E., and N.S. Smith, "Surface Acoustio Wave DustDeposition."

Fasching, G.E., T.W. Keech, Jr., and N.S. Smith, "Sensor Technology for Ash and Particle Laden Hot Gases."

Fasching, G.E., "3-D Capacitance Density Imaging System."

Fasching, G.E., and N.S. Smith, "High Resolution Capacitance Imaging system: Technical Note."

Flach, G.P., and M.N. Ozisik, "Whole Domain FunctionSpecification Method for Iinear Inverse Heat Conduction." 
Foster, D.E., and P.O. Witze, "wo-Component Laser Velocimeter Measurements in a Spark Ignjulon Engine."

Galo, P., H. Burnage, S.J. Yoon, and D. Lourme, "Distribution of Mean Concentration, Dropsize and Velocity, and Size-Velocity Correlations in the Spray of an Air-Assist Nozzle."

Gallagher, E., J.R. MacDonald, and R.J. Coleman, "Automatio Control of Froth Flotation at German Creek Preparation Plant Using the Century Autoflote Control system."

Gangwal, S.K., P.M. Grohse, D.E. Wagoner, D.J. Minick, C.M. Sparacino, and R.A. Zweldinger, "Pollutants from synthetic Fuels Production: Sampling and Analysis Methods for Coal Gasification."

Geney, J.-N., and B. Garret, "Instrumentation and Control Principles for Large Combined Cyoles."

Gerhart, S.A., and M.E. Thomas, "Evaluation of a Temperature Remote Sensing Technique."

Ghadiri, M., B. Carter, R.R. Rathbone, R. Clift, S.J. Medhurst, E.A. Rogers, and I.R. Summerfield, "Diagnosis of Gas Flow Patterns in Fluidised Beds."

Giel, T.V., Jr., and J.Y. Son, "Evaluation of the Laser Doppler Ve 'ooimeter for Particle sizing."

Giel, T.V., Jr., and J.-Y. Son, "In-Situ Particle Characterization."

Gilg, J., and M. Pflugbeil, "Planning of Noise Control Measures in Connection with the Retrofitting of the FGD systems in the Neurath Iignite-Fired Power Plant."

Given, P.H., "The Mobile Phase in Coals: Its Nature and Modes of Release."

Goates, S.R., and M.I. Lee, "Supercritical Fluid Chromatography/ Supersonic Jet Spectroscopy: Progress Report, Mar. 1, 1988May 31, 1988."

Goates, S.R., and M.I. Lee, "Supercritical Eluid Chromatography/ Supersonic Jet Spectroscopy: Progress Report, June 1, 1988Nov. 30, 1988."

Goff, D.R., "Optical Combustion Monitoring in Fossil Energy Processes." 
Gray, R.H., E.K. Chess, P.J. Mellinger, R.G. Riley, and D.I. Springer, "Health and Environmental Research on Complex organio Mixtures."

Greensberg, K.E., and R.J. Hargis, Jr., "Pulsed-Ultraviolet Iaser Raman Diagnostios of Low-Pressure Plasna Processing Discharges."

Griffiths, P.R., "Spectroscopic study of Coal structure and Reactivity: Quarterly Report."

Grohe, H.W., "Messen an Verbrennungsmotoren (Measurements on Internal Combustion Engines). 3. rev. ed."

Guedelhoefer, P., "Measuring of Particulates in Wet Flue Gases."

Haff, P.K., "Microscopic Modeling of Sound Waves in Granular Materials."

Hardesty, D.R., "Development and Application of Advanced Diagnostics Methods in Fossil Fuel Combustion studies."

Hardesty, D.R., D.J. Holve, R.P. Lucht, R.W. Schmieder, I. Thorne, D.A. Tichenor, J.C. Wang, and P.O. Witze, "An Assessment of Optical Diagnostics for in situ Measurements in -High Temperature Coal Combustion and Conversion Flows."

Hardesty, D., "In-Situ Real-Time Species Analysis of Particulates."

Harrison, E.K., and B.S. Thomas, "Spectroscopic Determination of Coal Tar Pitch Volatiles."

Harsha, P.T., "Instrumentation Requirements from the User's view."

Heinze, T., H. Krumreich, and W. Feuser, "Determination of Mixture Formation in an Injection Jet by Spontaneous Raman spectroscopy."

Hensel, J.P., "Nonisothermal Pyrometry Techniques."

Herbster, R.E., and D.F. Franczak, "Power Plant Diagnostics."

Hercules, D.M., "Characterization of Oxidized Coal Surfaces: Quarterly Report, Feb. 1988-Apr. 1988."

Herzel, P.J., "Coriolis-Type Mass Flowmeter." 
Ho, P., W.G. Breiland, and M.E. Coltrin, "Laser-Excited Fluorescence Studies of Gas-Phase Silicone Atoms in Silane Chemical Vapor Deposition."

Holcombe, N.T., "Proceedings of the AR\&TD (Advanced Research and Technology Development) Direct Utilization and Instrumentation and Diagnostics Review Meeting."

Holve, D.J., P.I. Meyer, L.J. Muzio, and G.H. Shiomoto, "On-Line, in situ, Particle Measurements in Large Scale Combustion systems."

Holve, D.J., "An On-Iine Hybrid Optical Probe (HOP) for Particle Counting."

Hubbard, C.W., and R.I. Gordon, "Chemical Sensors."

Hulse, C.O., R.S. Bailey, H.P. Grant, and J.S. Przybyszewsici, "High Temperature Static Strain Gage Development Contract Tasks 1 and 2 Interim Report."

Huston, G.C., Sr., and J.K. Wachter, "Development of an Extractive, Continuous Monitor to Analyze Hydrogen Chloride in CoalDerived Process Streams."

Ichikawa, T., K. Nagata, ano H. Karasawa, "Control Method of Coal Gasification Combined Cycle."

Irdi, G.A., P.C. Rohar, and L.F. Chaparro, "The Development of an Automated Image Analysis Method to Estimate Pyrite Particle Iiberation in Crushed Coals."

Irdi, G.A., and P.C. Rohar, "Validation of Image Anaiysis and Sample Pellet Preparation Methods for Estimating Pyrite Particle size Distribution in Crushed Coals."

Ito, O., H. Seki, and M. Iino, "Diffuse Reflectance Spectra in Near-I.R. Region of Coals: A New Index for Degrees of Coalification and Carbonization."

Jewett, S.Y., J.W. Robertson, Jr., and G.D. Woolbert, "Apparatus for Monitoring Low Level Combustibles."

Johnson, P., "Measurement of Flow Using Radioactive Tracers."

Johnson, R.G., "Flow Sensor Furnace Control."

Kadambi, J.R., "Laser Velocimeter Measurement of Solids in Multiphase Elow." 
Kadambi, J.R., A. Dybbs, R.V. Edwards, S. Bhunia, and R.C. Chen, "Development of a Refractive Index Matched Test Facility for Solid-Liquid Flow Studies Using Laser Velocimetry and some Initial Results, Sep. 1986-Feb. 1989."

Kadambi, J., "Laser Velocimeter Measurements of Solids in Multiphase Flows."

Karplus, H.B., A.C. Raptis, S. Lee, and T. Simpson, "The ANI Doppler Flowmeter."

Kashiwagi, T., "Temperature and Concentration Measurements in Combustion."

Kawatra, S.K., "Instrumentation and Control for Fine Coal Processing."

Keech, T.W., Jr., "Instrumentation Development for the METC 42-Inch Stirred, Fixed-Bed Coal Gasification: Final Technical Report."

Keech, T.W., Jr., "Fiber Optics, Deposition, and Process Control."

Kirby, P.J., R.E. Zachary, and F. Ruiz, "Infrared Thermometry for Control and Monitoring of Industrial Gas Turbine."

Kittelson, D.B., P.A. Kadue, H.C. Sherrer, and R.E. Lovrien, "Characterization of Diesel Particles in the Atmosphere. Final Report, 1978-1980."

Klingenberg, H., and J. Staab, "Time Resolved Measurements of Automotive Exhaust Emissions-Necessity and Limitations."

Klinzing, G.E., "Development of an In-Situ Hydrogen Measuring Instrument for Coal Liquefaction Processes."

Komori, I., "Radiation Wall Thickness Measuring system for Heat Exchange Tubes."

Koranyi, A., "Use of Thermal Analysis in Coal Energy Studies."

Kosel, T.H., and K. Anand, "Optoelectronic Velocimeter Development."

Kubicek, P., M. Volney, and P. Vopalecky, "The New Type On-Belt Scatter Radio-Metric Gamma Coal Ash Meter."

Kucukbayrak, S., D. Boersma, and R.J. van der Berg, "Gas Concentration Measurements in the Freeboard of a Fluidized Bed coal." 
Kuester, J.L., "Conversion of Cellulosic Wastes to Liquid Hydrocarbon Fuels, Vol 3: Supervisory Control System Development for an Indirect Liquefaction Process."

Kuroiwa, H., and Y. Oyanma, "Air-Fuel Ratio Detection Sensor."

LaNauze, R.D., and K. Jung, "Particle Temperature Measurement in a Fluidized Bed."

Lalin, H.S., I.E. Bermudez, and W.T. Fleming, "Soap Film Gas Flowmeter."

Laurila, M., "Tracing Plant Performance."

Laurila, M., "Assessing Plant Performance."

Laurila, M.J., "On-Line Ash Analysis: The Next Step."

Laurila, M.J., "The Application of On-Line Coal Slurry Ash Analyzers."

Laurila, M.J., and A.M. Hein, "Process Control Assures Peak Plant Performance."

Lawson, I.O., J.A. Reel, and T.W. Keech, Jr., "A System Identification Study: Methodology, Algorithms, and Application."

LeVert, F.E., "Slag Deposition Monitor."

Lee, S.H., and K.M. Myles, "Measurement of Alkali Vapors in PFBC Process Stream and Their Removal with a Fixed Granular-Bed Sorber."

Lee, S.H.D., and E.I. Carls, "Measurement of Alkali Vapor Concentration in the PFBC (Pressurized Fluidized-Bed Combustion) Flue Gas."

Lengyel, J., and E.L. Obermiller, "Interlaboratory Variability and Accuracy in Trace Elements Analyses of Coal."

Leone, A., J.W. Otvos, and M. Calvin, "Fuel Cell Oxygen Sensor for Trace Oxygen Analysis."

Ling, S.C., and H.P. Pao, "Optical Instrumentation and Study of Gas-Solid Suspension Flows."

Lodder, R., and J.B. Lefers, "Continuous On-Line Analysis of $\mathrm{NH}_{3}$ in Flue Gas Downstream Catalytic NO ${ }_{x}$ Reduction Plants" 
Logan, R.G., R.I. Pineault, and W.E. French, "A Sampling system for Real-Time Alkali Monitoring in High-Temperature, HighPressure Process Streams: Technical Note."

Lucht, R.P., "CARS Diagnostics of Internal Combustion Engine Processes."

Lynch, I.J., D.S. Webster, R. Sakurov, W.A. Barton, and T.P. Maher, "The Molecular Basis of Coal Thermoplasticity."

Macek, A., S.R. Charagundla, J.D. Allen, and H.G. Semerjian, "A Study of Combustion Spectra from an Entrained-Flow Gasifier."

Markuszewski, R., C.D. Chriswell, and G.A. Norton, "Development of Instrumental Techniques for Coal Surface Analysis: Analysis for Sulfur Forms in Coal and on Coal Surfaces."

Mathur, M.P., and J.M. Ekmann, "Apparatus for Measuring Slag or Ash in a Eurnace."

Maul, E., D. Wagner, and R. Goeldner, "Siacon-Equipment for the on-Iine Determination of the Silicon Content of Coal."

McCarty, D.I., J.A. Draeger, W.P. Chisholm, and R.R. Romanosky, Jr., "Instrumentation for On-Line Analysis of Fossil FuelDerived Gas Streams."

McClelland, J.F., "Development of Instrumental Techniques for Coal Surface Analysis: Advanced Spectroscopic Analysis of Coal Surfaces During Beneficiation."

Mehner, H., H. Berndt, D. Radeck, and R. Heinrich, "Moessbauser Investigations of Properties of Iron Containing Catalysts Used for Hydrogenation of Brown Coal at High Pressure."

Metzger, G.A., and J.A. Britten, "Data Acquisition System and Instrumentation for the Rocky Mountain I Coal Gasification Test."

Mieno, T., T. Nakajima, Y. Okada, and N. Oono, "Method of Compensating output from oxygen Concentration Sensor of Internal Combustion Engine."

Mikula, R.J., and M.W. Mikhail, "A Delta P Technique for the Prediction and Monitoring of Coal oxidation."

Mills, K.C., and J.M. Rhine, "The Measurement and Estimation of the Physical Properties of Slags Formed During Coal Gasification." 
Mollenhauer, K., and G. Israel, "Method of Monitoring Particulate Emissions fror! Industrial Vehicles."

Morelli, J.J., Z.A. Wilk, D.M. Hercules, P.C. Lyons, C.A. Palmer, and J.D. Fletcher, "Direct Analysis of Coal Macerals Using Laser Micro Mass Spectrometry."

Moriyoshi, Y., T. Kamimoto, M. Yagita, H. Kobayashi, and H. Morita, "Measurement and Numerical simulation of In-Cylinder Air Motion of a Transparent Engine (First Report). Air Motion in a Pancake-Type Combustion Chamber."

Nadkarni, R.A., and J.M. Brewer, "Semiautomatic Proximate Analysis of Fossil Fuels."

Najar, M.S., and T.F. Leiningex, "Thermocouple for Use in a Hostile Environment."

Nakayama, M., "Particle Data Reduction in Japan."

Nelson, E.T., W.H. Fischer, J.V. Lipka, M.D. Rutkowski, and R. Zaharchuk, "Assessment of Instrumentation Needs for Advanced Coal Power Plant Applications: Final Report."

Nip, M., W. Genuit, J.J. Boon, J.W. Deleeuw, P.A. Schenck, M. Blazso, and T. Szekely, "Chemical Characterization of Hungarian Brown Coal by Currie-Point Pyrolysis-Low-Energy Electron Impact Mass Spectrometry and Multivariate Analysis."

O'Leary, M., Z. Ii, and S.J. Fonash, "Metal-Sensing LayerSemiconductor and Metal-Sensing Layer-Metal Heterostructure Gas Sensors."

Obuchi, A., A. Ohi, H. Aoyama, and H. Ohuchi, "Evaluation of Gaseous and Particulate Emission Characteristics of a SingleCylinder Diesel Engine."

Odom, M.K., "Comparison of Two Pyrometers Used to Calibrate Primary Standards for Laboratory's Tungsten Filament Lamps."

Oldenborg, R.C., "Optical Detection of Corrosive Compounds."

Oldenborg, R.C., and S.L. Baughcum, "Optical Detection of Alkali Compounds."

Onodera, J., H. Kawaguchi, K. Komatsu, and N. Koyangi, "Results of On-Iine Ash Content Measurement with Transmission-Type Coal Ash Content Meter Using Two Radioactive Sources." 
Ottesen, D.K., J.C.F. Wang, and I.J. Radziemski, "Real-Time Laser Spark Spectroscopy of Rarticulates in Combustion Environments."

Park, J.T., "Measurements in Solids Transport."

Park, J.T., R.J. Mannheimer, T.A. Grimely, and T.B. Morrow, "Pipe Flow Measurements of a Transparent Non-Newtonian Slurry."

Perez, J.M., R.E. Jass, and D.G. Leddy, "Chemical Methods for the Measurement of Unregulated Diesel Emissions -- Carbonyls/ Aldehydes, Particulate Characterization, Sulfates, and $\mathrm{PAH} / \mathrm{NO}_{2} \mathrm{PAH}$."

Powers, J., and D. Netzer, "Combustion/Particle Sizing Experiments at the Naval Postgraduate Scholl Combustion Research Laboratory."

Priestman, G.H., and J.R. Tippetts, "Development and Potential of Power Fluidics for Process Flow Control."

Proudfoot, B., "Coal Sampling."

Rao, N.V., "Elemental Analysis of Coal Ash Using EnergyDispersive X-Ray Fluorescence."

Raphaelian, L.A., and D.W. Green, "Advanced Instrumental Methods for Analyzing Organics in Solid Waste."

Raptis, A.C., "Advanced Research in Instrumentation and Control Technology."

Reed, G., "Measurement of Residence Times and Residence-Time Distributions."

Rehm, B.W., B.J. Christel, T.R. Stolzenburg, and D.G. Nichols, "Field Evaluation of Instruments for the Measurement of Unsaturated Hydraulic Properties of Fly Ash."

Reinicke, w.L., "Sound Emissions of the Elue Gas Denoxing Plants for Large Furnaces."

Rentz, O., J. Remmers, and E. Plinke, "Workshop od. Emission Control Costs: Methodology and Example Cases -- Proceedings."

Rhee, H.S., J.R. Koseff, and R.L. Street, "Simultaneous Flow and Temperature Field Visualization in a Mixed Convection Flow."

Richardson, W.R., and E.D. Walker, "Bonding Lexan and Sapphire to Form High-Pressure, Flame-Resistance Window." 
Rigin, V.I., "Ion Chromatographic Determination of Halogens, Nitrogens, Phosphorus, and Sulfur in Coal."

Romanosky, R., "In-Situ Methods for Elemental Analysis of Hot Gas Streams by Laser-Induced Breakdown Spectroscopy."

Romberg, T.M., "Trends in Coal Preparation On-Line Optimization and Control."

Rongbau, L., S. Zengmin, and I. Bailing, "Structural Analysis of Polycyclic Aromatic Hydrocarbons Derived from Retroleum and Coal by $C$ and H-n.m.r. Spectroscopy."

Rosenberger, H., G. Scheler, and E. Kuenstner, "Characterization of Some Coals and Coal Intercalations by High-Resolution $\mathrm{H}$ (BR-24/MAS at $270 \mathrm{MHz}$ ) and (CP/MAS) n.m.r. in Solids."

Rumelfanger, R., S.A. Asher, and M.B. Perry, "UV Resonance Raman Characterization of Polycyclic Aromatic Hydrocarbons in Coal Liquid Distillates."

Russell, A.D., "Telemetry of Thermocouple Data from Very High Speed Gas Turbines."

Russhard, P., "Digital Telemetry systems for Gas Turbine Development."

Rustschev, D.D., "Application of DTA- and IG-Analysis to Investigate the Carbonization Process."

Savage, K.I., "Sampling Variance: Bias and Reproducibility."

Seehra, M.S., "Use of Magnetic Studies, Electron Spin Resonance, F'TIR, and Photoacoustic Spectroscopy in Coal Research."

Seehra, M.S., B.A. Bajura, and T. Karolichik, "Instrumentation for Laboratory Characterization and Process Stream Measurement of Coal and Coal products."

Seese, J.R., "Plant Operation Improved by Retrofit PLCs."

Seibert, G., "Status of Holographic Interferometry at WrightPaterson Air Force Base."

Sheen, S.H., and A.C. Raptis, "A Feasibility study on Advanced Techniques for On-Line Monitoring of Coal Slurry Viscosity."

Sheen, S.H., A.C. Raptis, J.R. Bobis, S. Lee, and T. Simpson, "Evaluation of Active Ultrasonic Cross-Correlation Technique in Coal/Liquid Pipe Flow Measurements." 
Sheen, S.H., A.C. Raptis, S. Lee, T. Simpson, and J.P. Bobis, "Ultrasonic Techniques for Coal slurry Flow and Viscosity Measurements."

Sheen, S.H., D.E. Karvelas, and A.C. Raptis, "Nonintrusive Ultrasonic Flow Measurement Techniques and Their Applications to Btu Metering."

Silver, J.A., and A.C. Stanton, "An Infrared Diode Laser Spectrometer with Enhanced Sensitivity for Combustion Research."

Sklarew, D.S., J.C. Evans, and K.B. Olsen, "Multielement Detector for Gas Chromatography."

SkIyar, M.G., S.A. Slobodski, V.K. Dang, and G.A. Gamazina, "Optical Texture and Coke Reactivity."

Solomon, E.R., and R.M. Carangelo, "FT-IR Analysis of Coal."

Solomon, P.R., and D.G. Hamblen, "Measurements and Theory of Coal Fyrolysis, a Topical Report."

Solomon, E.R., D.G. Hamblen, M.A. Serio, L.D. Smoot, and S. Brewster, "Measurement and Modeling of Advanced Coal Conversion."

Solomon, P.R., M.A. Serio, D.G. Hamblen, P.E. Best, K.R. Squire, R.M. Carangelo, J.R. Markham, and S.G. Heniger, "Coal Gasification Reaction with on-Iine In-Situ FT-IR Analysis."

Spiro, C.L., D.S. Holmes, J. Lobos, and D.H. Maylotte, "Use of $\mathrm{X}$-ray Computed Tomography to Examine Microbial Desulfurization of Lump Coal."

Stephens, J.W., J.L. Hall, H. Solka, W.B. Yan, R.F. Curl, and G.P. Glass, "Rate Constant Measurements of Reactions of $\mathrm{C}_{2} \mathrm{H}$ with $\mathrm{H}_{2}, \mathrm{O}_{2}, \mathrm{C}_{2} \mathrm{H}_{2}$, and NO Using Color Center Laser Kinetic
spectroscopy.

Sugimoto, Y., Y. Miki, Y. Tanba, M. Oba, and M. Yamada, "Composition of Polar Compounds in Coal-Derived Distillable Iiquids."

Sun, Y.Z., and R.A. Bajura, "Deposition Rate Sensor Development Project."

Supaluknari, S., F.P. Larkins, P. Redlich, and W.R. Jackson, "An FTIR Study of Australian Coals: A Comparison of Structural and Hydroliquefaction Data."

Synder, R., and L. Hesselink, "High Speed Tomographic Optical Data Acquisition Systems for Combustion Research." 
Taylor, D.J., "Advanced Coherent Raman Diagnostios for Coal Gasification Streams."

Taylor, L.T., "Identification of Nonvolatile Coal Derived Products via Chromatography Coupled with on-Iine FTIR Detection."

Tichenor, D.A., R.E. Mitchell, K.R. Hencken, and S. Niksa, "Simultaneous in situ Measurement of the Size, Temperature, and Velocity of Partioles in a Combustion Envirunment."

Troutt, W.R., R. Hanle, N. Kamalu, F. Wen, and J.N. Chung, "Visualization Techniques for Understanding Particle Dispersion in lurbulent Shear Elows."

Tsurusaki, S., "Diagnostic System for Exhaust Gas Recirculation Device."

Vannier, M.W., and W.A. Ellingson, "Quantitative Computed Tomography."

Venkateswarlu, P., M.C. George, J.M. Thompson, and V. Subba Rao, "Iaser Diagnostics of Mineral Matter and Combustion Processes in Coal."

Verkade, J.G., "Development of Instrumental Techniques for Coal Surface Analysis: Functional Group Analysis in Coal by $31 P$ NMR Spectroscopy Quarterly Report."

Voglex, T.C., and W. Weissman, "Thermodynamic Availability Analysis for Maximizing a System's Efficiency."

Vural, H., P.M. Walsh, J.D. Teare, A.F. Saraofim, and J.M. Beer, "Coal Particle Movement on a Fluidized Bed Combustor Surface."

Walter, J.B., and L.A. Lott, "Ultrasonic Detection of Voids in Ceramic Composites."

Walter, J.B., L.A. Lott, and P.M. Gammell, "Ultrasonic Characterization of Porosity in Advanced SiC Ceramic Composites."

Wernet, M.P., and L.G. Oberle, "Laser Anemometry Techniques for Turbine Applications."

Williams, M.C., and D.C. Cicero, "The Department of Energy's Program for Characterizing PFBC Exhausts with the METC FiberOptic Alkali Monitor."

Wilson, R., C.A.F. Johnson, J.E. Parker, and A.A. Herod, "NO+ CIMS of Saturate Fraction obtained for a Coal Liquefaction Recycle Solvent." 
Wolber, w.G., "Sensors for Heavy Duty Engines and Vehtcles."

Woodruff, S.D., R.L. Plneault, R.R. Romanosky, and R.J. Anderson, "On-Line Measurement of the Alkall and Particulate Loading of the Process Stream of a Fixed-Bed Gasifier."

Wright, B.W., G.A. Ross, and R.D. Smith, "Caplilary zore Electrophoresis of Fuel Materials."

Wykes, J.S., M.J. Gibson, I. Adsley, G.M. Croke, and J... Hoddy, "Nucleonic Methods for the Measurement of Coal and Ash."

Yamada, T., "Air/Fuel Ratio Sensor Apparatus for Use with Internal Combustion Engine."

Yaney, P.P., "New Aurlysis Scheme for Kilohertz Flame Temperatura Measurements Using Two Rotational Raman Lines and a CW Laser."

Yellets, J.P., S.M. Hsu, and E.E. Klaus, "Design and Construction of a state-of-the-Art High Temperature Tribometer: Final Report."

Zhidong, C., and W. Xiangsheng, "A Preliminary Mossbauer Spectroscopic study of the Catalytic Action of Iron Based Catalysts in Lignite Liquefaction."

Zhiwei, S., and G. Xuli, "studies on Pyrolysis -- Gas Chromatography of Coal."

$4: 900827 j j \cdot 1 i_{i} i$ 

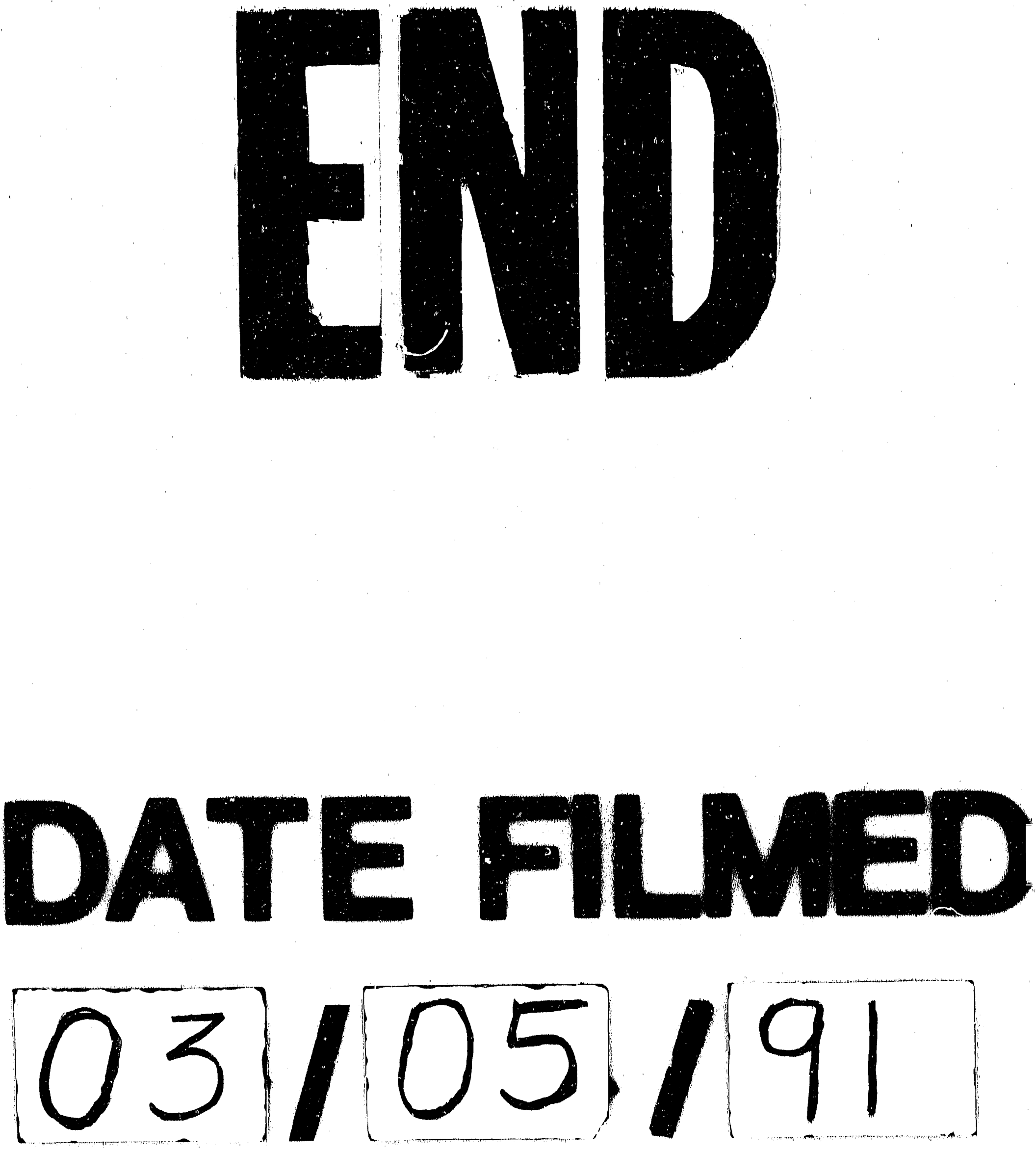
